\title{
Structural Heterogeneities and Paleo Fluid Flow in an Analog Sandstone Reservoir 2001-2004
}

\section{By}

\section{David Pollard and Atilla Aydin}

Department of Geological and Environmental Sciences

Stanford University

Stanford, California 


\section{TABLE OF CONTENTS}

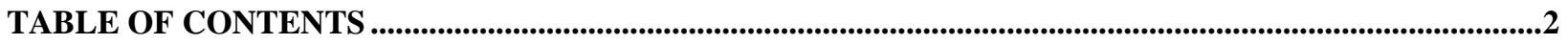

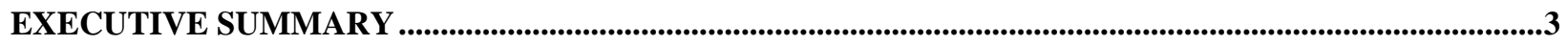

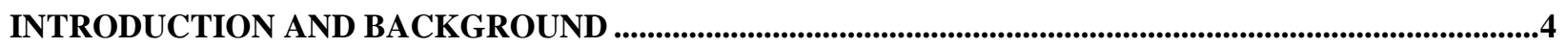

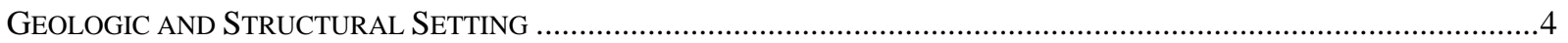

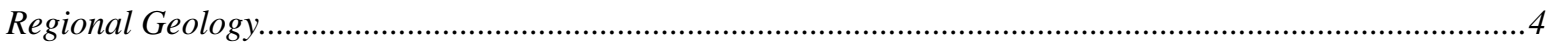

Principal Structural Elements of the Aztec Sandstone....................................................................................5

SUMMARY RESULTS FROM THE GRANT PERIOD .....................................................................................6

1. CHEMICAL CHARACTERIZATION OF COLORED ALTERATION BANDS AND PALEO FLUID FLOW ..............................6

2. CHARACTERIZING FAULT ZONE PERMEABILITY AND REPRESENTING IT IN RESERVOIR FLOW MODELING ................7

3. MECHANICAL CHARACTERIZATION OF COMPACTION BANDS AND THEIR EFFECT ON BULK PERMEABILITY ..............9

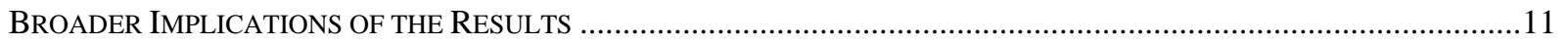

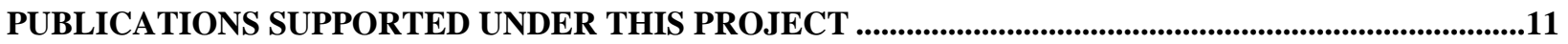

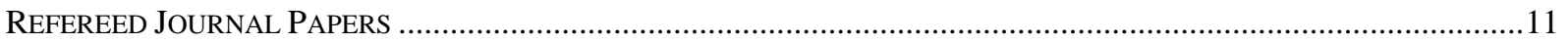

ROCK FRACTURE PROJECT REPORTS AND DiSSEMINATION OF RESULTS TO INDUSTRY: .......................................12

ABSTRACTS AND PAPERS PRESENTED AT NATIONAL AND INTERNATIONAL MEETINGS .........................................13

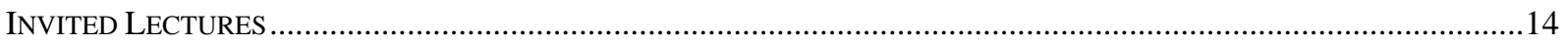

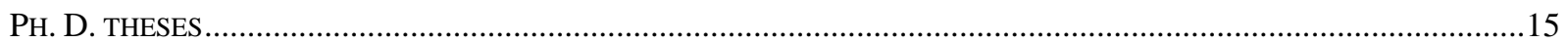

DOE, BES, and Chemical Sciences, Geosciences, and Biosciences Division 


\section{EXECUTIVE SUMMARY}

Fractures and faults are brittle structural heterogeneities that can act both as conduits and barriers with respect to fluid flow in rock. This range in the hydraulic effects of fractures and faults greatly complicates the challenges faced by geoscientists working on important problems: from groundwater aquifer and hydrocarbon reservoir management, to subsurface contaminant fate and transport, to underground nuclear waste isolation, to the subsurface sequestration of $\mathrm{CO}_{2}$ produced during fossil-fuel combustion. The research performed under DOE grant DE-FG0394ER14462 aimed to address these challenges by laying a solid foundation, based on detailed geological mapping, laboratory experiments, and physical process modeling, on which to build our interpretive and predictive capabilities regarding the structure, patterns, and fluid flow properties of fractures and faults in sandstone reservoirs. The material in this final technical report focuses on the period of the investigation from July 1, 2001 to October 31, 2004.

The Aztec Sandstone at the Valley of Fire, Nevada, provides an unusually rich natural laboratory in which exposures of joints, shear deformation bands, compaction bands and faults at scales ranging from centimeters to kilometers can be studied in an analog for sandstone aquifers and reservoirs. The suite of structures there has been documented and studied in detail using a combination of low-altitude aerial photography, outcrop-scale mapping and advanced computational analysis. In addition, chemical alteration patterns indicative of multiple paleo fluid flow events have been mapped at outcrop, local and regional scales. The Valley of Fire region has experienced multiple episodes of fluid flow and this is readily evident in the vibrant patterns of chemical alteration from which the Valley of Fire derives its name.

We have successfully integrated detailed field and petrographic observation and analysis, process-based mechanical modeling, and numerical simulation of fluid flow to study a typical sandstone aquifer/reservoir at a variety of scales. We have produced many tools and insights which can be applied to active subsurface flow systems and practical problems of pressing global importance. 


\section{INTRODUCTION AND BACKGROUND}

In 1994, we proposed to work on fracture localization and its impact on fluid flow in faulted and folded structures located in the Moab Valley of Arches National Park (Utah), the Kaibab Monocline (Utah) and the Valley of Fire State Park (Nevada). That proposal led to the DOE Basic Energy Sciences project entitled Development of Fracture Networks and Clusters: Their Role in Channelized Flow in Reservoirs and Aquifers (DE-FG03-94ER14462). This project has been renewed twice-in 1997 and 2001-under the title of Structural Heterogeneities and Paleo Fluid Flow in an Analog Sandstone Reservoir, which has focused specifically on the Jurassic Aztec Sandstone exposed in the Valley of Fire as an exhumed paleo reservoir/aquifer. The material in this report is primarily from the last period of the investigation (2001-2004).

\section{Geologic and Structural Setting}

\section{Regional Geology}

The Valley of Fire State Park is located about 60 miles northeast of Las Vegas, west of the Overton Arm of Lake Mead and northeast of the Muddy Mountains in southeastern Nevada (Figure 1 inset). It is within the Basin and Range tectonic province just west of the Colorado Plateau. This area was first studied by Longwell (1920, 1946, 1960, 1962, 1963) and later by Bohannon (1977, 1983) and Carpenter and Carpenter (1994). The Aztec Sandstone, which makes up the bulk of the exposures in the Park where it is up to $1.4 \mathrm{~km}$ thick, is a Jurassic age subarkosic quartz arenite and represents the youngest pre-orogenic rock unit. It overlies the Triassic Moenave and Chinle formations and, within the Park, is itself overlain by syntectonic Cretaceous detrital rocks of the Willow Tank formation and Baseline Sandstone and Tertiary units.

The major structural features in the area include the Muddy Mountains to the south and the Northern Muddy Mountains to the west (Figure 1), where the Aztec Sandstone is overthrust by Paleozoic rocks of mostly carbonate lithology. This fault is known as the Muddy Mountain thrust and corresponds to late Mesozoic contractional deformation associated with the Sevier Orogeny (Armstong, 1968). The Valley of Fire region is separated from the Muddy Mountains by a northwest-trending fault system known as the Arrowhead Fault, which has a complicated kinematic history. Within the Park, the Aztec Sandstone is thrust over the synorogenic Willow Tank and Baseline Sandstones. Later in Tertiary time (starting from mid-Miocene) the region was subjected to widespread Basin and Range extensional and strike slip deformation (Bohannon, 1983; Anderson and Barnhard, 1993a,b).

This progression of geotectonic processes has manifest itself in the varied and complex suite of structural elements now exposed in the Valley of Fire (Figure 2), as well as in the extensive and colorful hydro-chemical alteration from whence the area derives its name. 


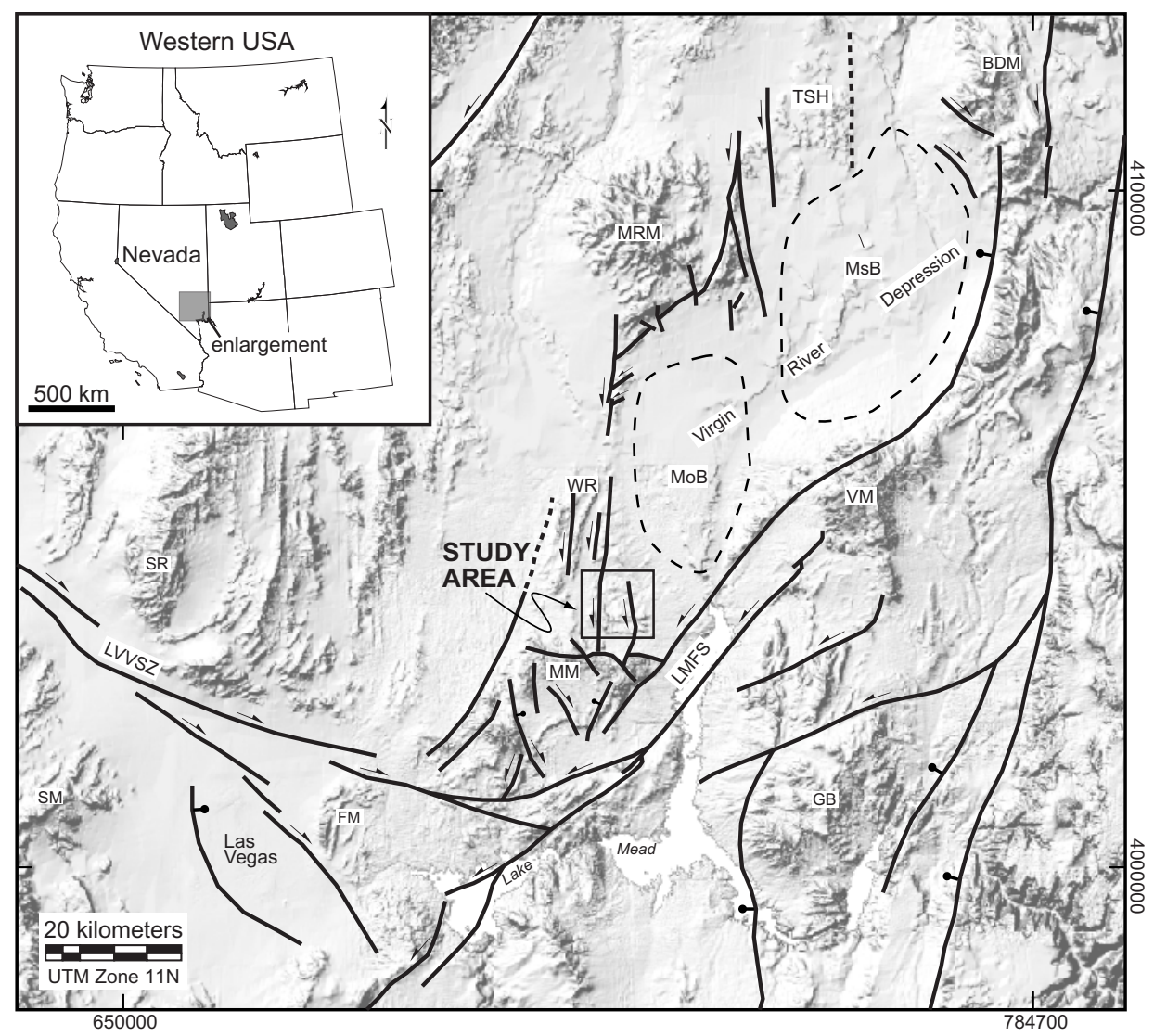

Figure 1. Location and generalized map of Cenozoic faults in the Valley of Fire region of southern Nevada. Heavy lines are faults. Arrows indicate predominant sense of slip for strike-slip faults. Ball and tick marks indicate hanging wall of predominat dip-slip faults. LMFS = Lake Mead Fault System, LVVSZ = Las Vegas Valley Shear Zone, BDM = Beaver Dam Mountains, FM = Frenchman Mountain, GB = Gold Butte, $\mathrm{MoB}=$ Mormon sub-basin, $\mathrm{MsB}=$ Mesquite sub-basin, $\mathrm{MM}=$ Muddy Mountains, $\mathrm{MRM}=$ Mormon Mountains, $\mathrm{SM}=$ Spring Mountains, $\mathrm{SR}=$ Sheep Range, $\mathrm{TSH}=$ Tule Spring Hills, VM $=$ Virgin Mountains, WR $=$ Weiser Ridge. Base-image is a mosaic of 1:250,000 USGS DEMs. Faults from Stewart and Carlson (1978), Bohannon (1983b), Bohannon (1992), Anderson and Barnhard (1993), Axen (1993), Campagna and Aydin (1994), and Beard (1996).

Geologic Time Scale

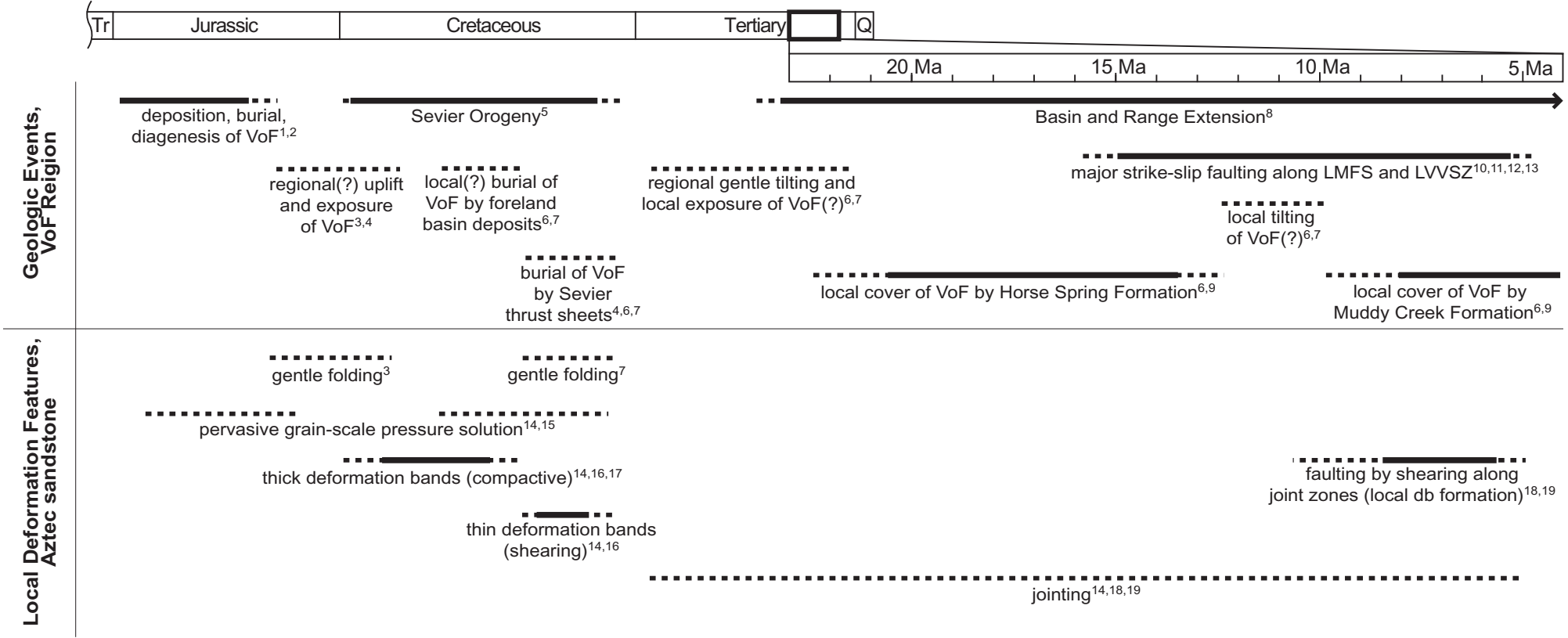

Figure 2. Summary of geologic and tectonics events for the Aztec sandstone in the vicinity of the Valley of Fire, southern Nevada. References are as follows: 1Poole (1964); 2Marzolf (1983); 3Fleck (1970); 4Brock and Engelder (1977); 5Armstrong (1968); 6Bohannon (1983a); 7Carpenter and Carpenter (1994); 8Zoback et al. (1981); 9Bohannon (1984); 10Beard (1996); 11Campagna and Aydin (1994); 12references in Duebendorfer et al. (1998); 13Langenheim et al. (2001) and referenced therein; 14Taylor (1999); 15Flodin (1999); 16Hill (1989); 17Sternlof (2001); 18Myers (1999). 


\section{Principal Structural Elements of the Aztec Sandstone}

During the course of our work in the Valley of Fire, we have documented the following fundamental structural elements in the Aztec Sandstone as listed below in chronological order of formation:

Deformation bands_-both shear and compaction dominated;

Joints and sheared joints; and

Joint-based fault zones.

Field examples of each of these types of structures are pictured in Figure 3.

Deformation bands: Deformation bands are thin, tabular structures millimeters to centimeters thick and meters to hundreds of meters in extent. Commonly found in porous sandstone such as the Aztec, they accommodate compaction and/or shearing via granular rearrangement and cataclasis with related pore volume reduction Unlike other types of brittle fractures such as joints, deformation bands exhibit a continuous distribution of displacement discontinuity rather than discrete surfaces (fracture walls). Shear bands display a dominance of shear displacement and related comminution, and tend to occur in closely spaced sets of mm-thick bands often associated with the adjacent development of a discrete slip surface. Pure compaction bands are characterized by negligible primary shear and limited comminution, and tend to occur as more widely spaced sets of cm-thick bands not immediately associated with adjacent slip surfaces or other faults.

Though sparse in the lower Aztec, the upper Aztec contains extensive, generally anastamosing arrays of thick compaction bands exhibiting a dominant, though variable NNW trend and steep ENE dip (Figure 3a). These thick compaction bands comprise the oldest structural fabric in the Aztec and may be genetically related to regional tectonic compression associated with Sevier overthrusting. Low-angle, often bedding-parallel shear bands, which exhibit a consistent top-to-the-east offset of the older compaction bands, are also common (Figure 3a). Shear bands that cut across bedding also occur, both individually and in lattice-like zones reminiscent of Riedel shear (Figure 3b). In all cases where timing relations are evident, shear banding is seen to postdate compaction banding. Both the density of deformation banding and the relative abundance of shear bands increase toward the top of the Aztec in proximity to the Willow Tank Thrust.

Joints: Opening-mode fractures, or joints, are also abundant in the Aztec Sandstone (Figure 3c) and exhibit at least four different characteristic geometric and geomorphic patterns in outcrop. Based on abundant cross-cutting relationships, all jointing appears to postdate deformation banding, and many joints are directly related to fault zone evolution. We interpret those widely distributed joints not directly related to faulting as being associated with the regional effects of Cenozoic Basin-and-Range extension. In certain locations, these tectonic 

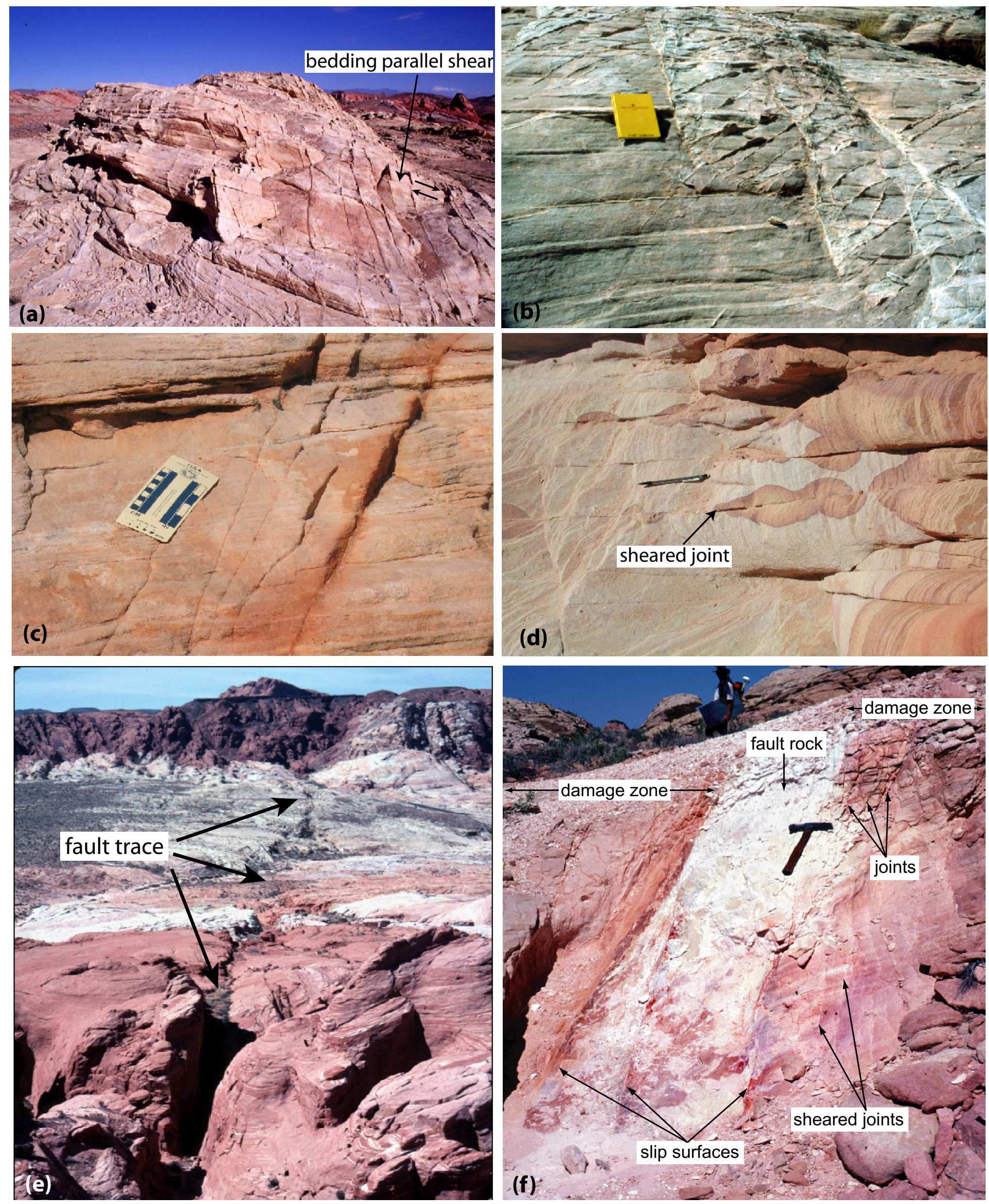

Figure 3. Principal structural elements of the Aztec Sandstone in the Valley of Fire: (a) sub-parallel array of thick, steeply dipping compaction bands (note bedding parallel shear); (b) zone of dense deformation banding suggestive of Riedel shearing; (c) typical tectonic joint set; (d) joint set associated with diagenetic alteration indicative of fluid flow (note sheared joint); (e) geomorphic expression of strike-slip fault trace; (f) cross section of a mature, joint-based strike-slip fault. 
joints have accommodated subsequent shearing, as indicated by offset markers (Figure 3d), and may have been exploited during fault zone formation (see section immediately below). A final stage of jointing appears to postdate all other deformation in the area and may well be related to unloading during uplift and erosion.

Faults: Joint-based faulting as a prominent deformation mechanism in sandstone was first identified by work conducted under this DOE-supported research program. An important component of our work in the Valley of Fire has centered on recognizing and describing this hierarchical process of fault evolution, which begins with the shearing of pre-existing joints to form tail cracks, and leads progressively to interconnected zones of fragmentation and the eventual formation of a through-going seam of fault rock (Figure 3e). The Aztec Sandstone in the Valley of Fire is dissected by a dense, hierarchical network of sub-vertical, left- and rightlateral strike-slip faults (with minor normal slip component) formed in this way.

\section{SUMMARY RESULTS FROM THE GRANT PERIOD}

Over the period of the current grant, we have pursued an integrated research program to study structural heterogeneities-deformation bands (Sternlof et al., 2003b), joints, sheared joints and faults (Flodin, 2003)—within the eolian Aztec sandstone at the Valley of Fire, NV. The purpose has been to understand how these structural fabrics affect groundwater and hydrocarbon flow, and to develop conceptual and mechanical models for how the structures evolve. Our efforts have been focused on three distinct, but complementary sub-projects: (1) Chemical characterization of colored alteration bands and their interpretation as evidence for paleo fluid flow; (2) Fault zone permeability upscaling based on field data and fluid-flow modeling, and the representation of fault permeability in reservoir simulation; and (3) Mechanical characterization of compaction bands in sandstone and their aggregate influence on bulk permeability. Results from these three sub-projects are summarized below.

\section{Chemical characterization of colored alteration bands and paleo fluid flow}

This sub-project focused on a sequence of diagenetic alteration zones with distinct colors in the Aztec Sandstone and assessed the effect of structural heterogeneities on paleo-fluid flow. Each alteration color corresponds to specific types of Fe oxides and hydroxides, predominantly hematite and goethite (Figure 5) and provides a record of paleo-fluid flow across the sandstone. We mapped the distribution of these alteration zones and their cross-cutting relations with Basin and Range style high-angle faults and with the most frontal thrust-sheet of the Cretaceous Sevier orogenic belt. The high-angle faults mechanically offset some of the alteration layers whereas other layers are deflected in the vicinity of the faults and clearly postdate some or all of the fault slip. 
Upper Aztec

\section{(iron oxide stained)}

Virgin Mountains, southwestern Utah

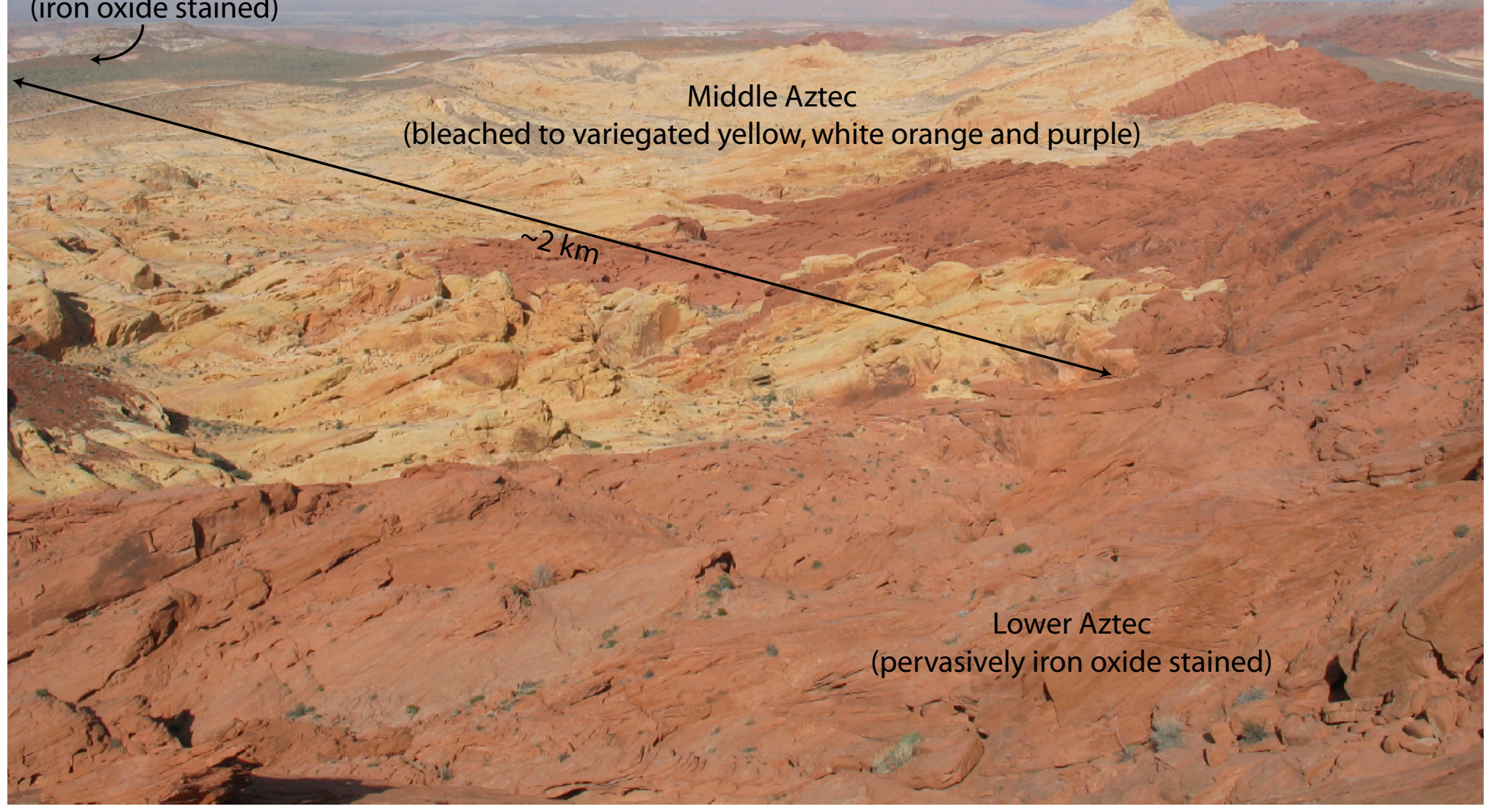

Figure 4. Eastward view of the Aztec Sandstone in the Valley of Fire State Park, NV from near the Rainbow Vista overlook. The sharp contact between the brick red lower Aztec and bleached middle Aztec, which is not strictly stratigraphic, meanders across the foreground and off to the upper right of the photo. Red-stained uppermost Aztec is just visible to the upper left of the photo, approximately $2 \mathrm{~km}$ from the lower contact along a trend roughly parallel to the NNE regional stratigraphic dip of $\sim 30$ degrees. The crest of the Virgin Mountains of southwestern Utah, just visible in the background, is approximately 20 miles distant. 
(a)

1. Late Jurassic
syndepositional
reddening

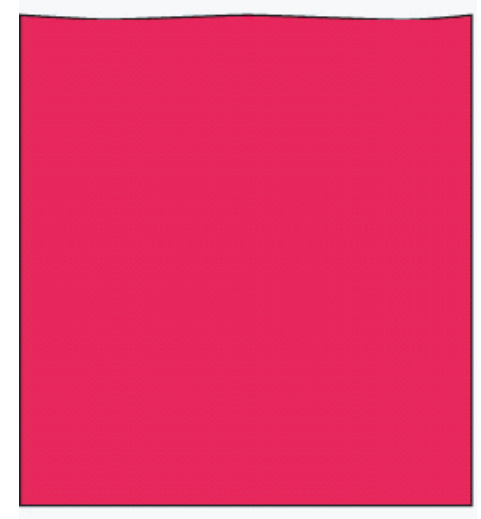

(b) Hematite grain coats

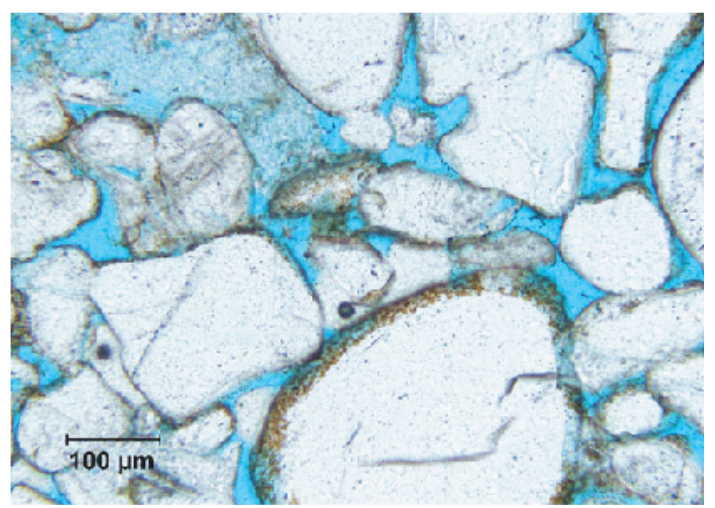

(c) Deformation bands

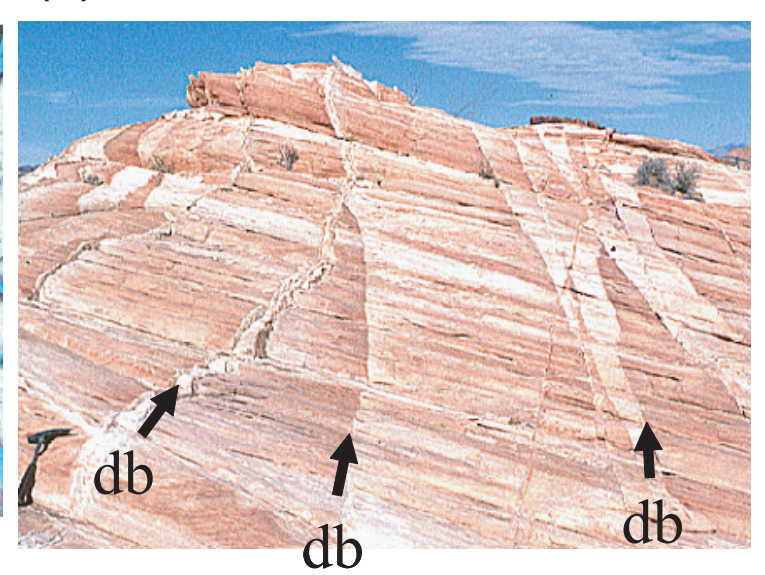

\section{Tertiary} mixing of meteoric water with basinal fluids during faulting $\downarrow \odot \otimes \uparrow$
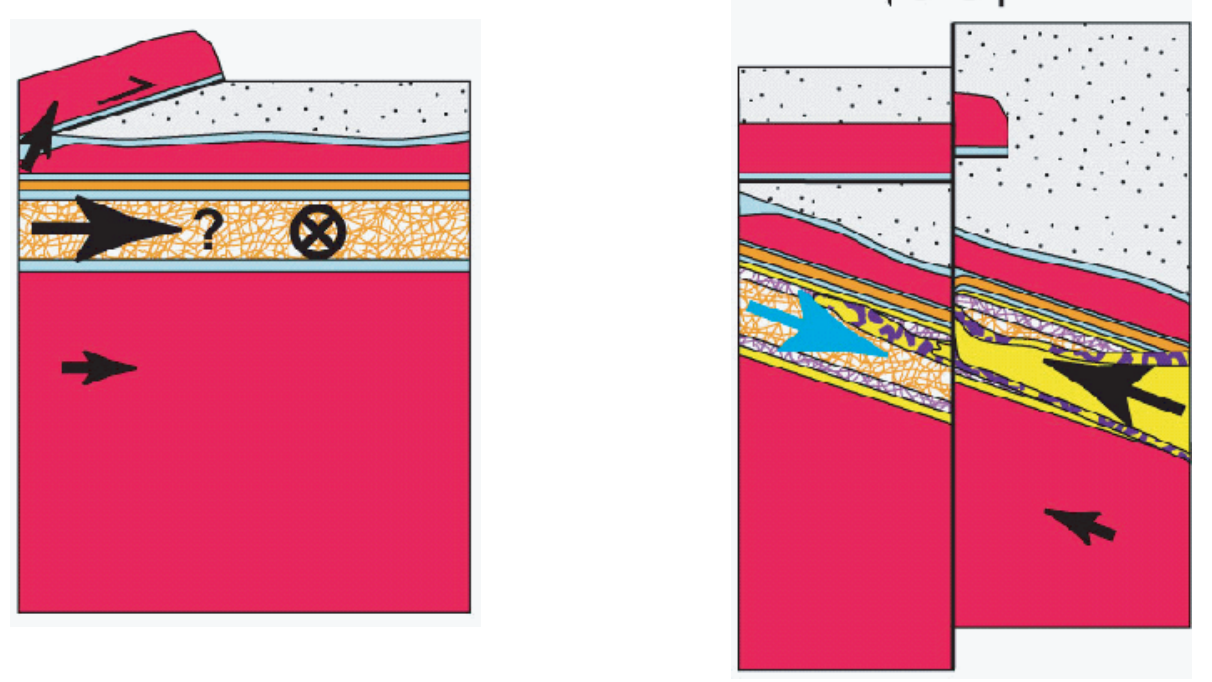

(d) Strike-slip and normal faults

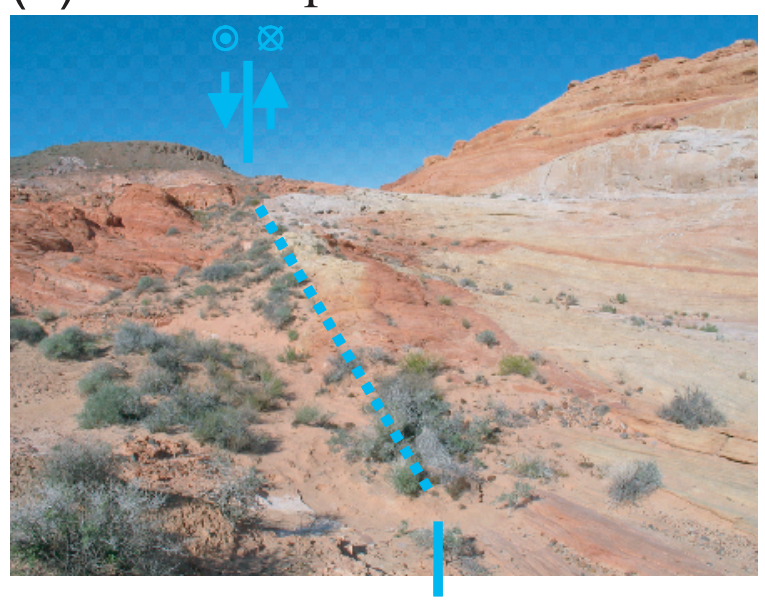

Figure 5. (a) Alteration history of the Aztec Sandstone From Late Jurrassicc through Late Cretaceous and to midTertiary. (b) Photomicrograph of the hematite grain coats that result in the bright red color of the sandstone in outcrop.

(c) Asymmetric staining adjacent to deformation bands consistent with their effect as baffles to fluid flow.

(d) Interaction between a fault and alteration bands as indicated by deflection of one of the alteration bands thereby becoming subparallel to the fault in its proximity. 
Based on these and other cross-cutting relations, we have reconstructed the fluid flow and alteration history of the sandstone formation (Figure 5a) (Eichhubl et al., 2004). The alteration history starts with the syndepositional formation of hematite grain coats that stain the formation uniformly red. A first bleaching and Fe remobilization stage was associated with Late Cretaceous Sevier thrusting. Characteristic of this alteration is the effect of deformation bands on the distribution of remobilized Fe oxides consistent with their effect of flow baffles (Figure 5c). A second flow and alteration event is concurrent with Miocene Basin and Range faulting. Figure $5 d$ shows an example of one of the alteration bands turning in the proximity of a fault. The alteration front clearly "saw" this fault. The cataclastic core of these faults has a measured core plug permeability 2 to 3 orders of magnitude lower than the surrounding host sandstone suggesting that the deflection of these bands is due to the disturbance in the fluid flow field. Faults composed of sheared joints in sandstone are found to be preferred conduits for flow parallel to, and barriers to fluid flow across, the fault. The deflection of chemical alteration bands formed by the precipitation of iron oxides (predominantly hematite) parallel to the fault likely resulted from a reduction in fluid flow velocity across the fault. The position and thickness of these alteration bands is controlled by precipitation and reduction kinetics and thus sensitive to local variations in flow velocity.

This study also illustrated that structures can impart significant hydraulic heterogeneity in otherwise fairly homogeneous sandstone aquifers. In addition, we have been able to document a prolonged history of tectonically controlled fluid flow in this sequence. The effect of structural discontinuities such as deformation bands and joints (Figure 6a and b, respectively) on fluid flow can be assessed qualitatively based on the distribution of chemical alteration along these structures. Iron oxides such as hematite and goethite are particularly well suited for such an assessment because their distribution is easily observed in the field. Iron oxides are precipitated from oxidizing (meteoric) waters and dissolved in reducing waters (e.g. formation fluids that are or have been in contact with hydrocarbons).

\section{Characterizing fault zone permeability and representing it in reservoir flow modeling}

We have mapped and analyzed how the pattern of strike-slip faults composed of left and right lateral faults with a consistent intersection angle developed in the Valley of Fire (Figure 6) (Flodin and Aydin, 2004). As shown in the conceptual model (Figure 7), the process is hierarchical and results in the first order left lateral faults bounding second order nested right lateral faults which, in turn, bound the third order left lateral faults, and so on. Fault segments and their distribution within a shear zone play a crucial role in this hierarchical process. The most critical mechanical process is splay fracturing (Figure $7 \mathrm{~b}$ ) which can be analyzed by mechanical models including the principal stress directions .The range of median splay fracture angles under the conditions simulated in the model study is 22 to 50 degrees. 


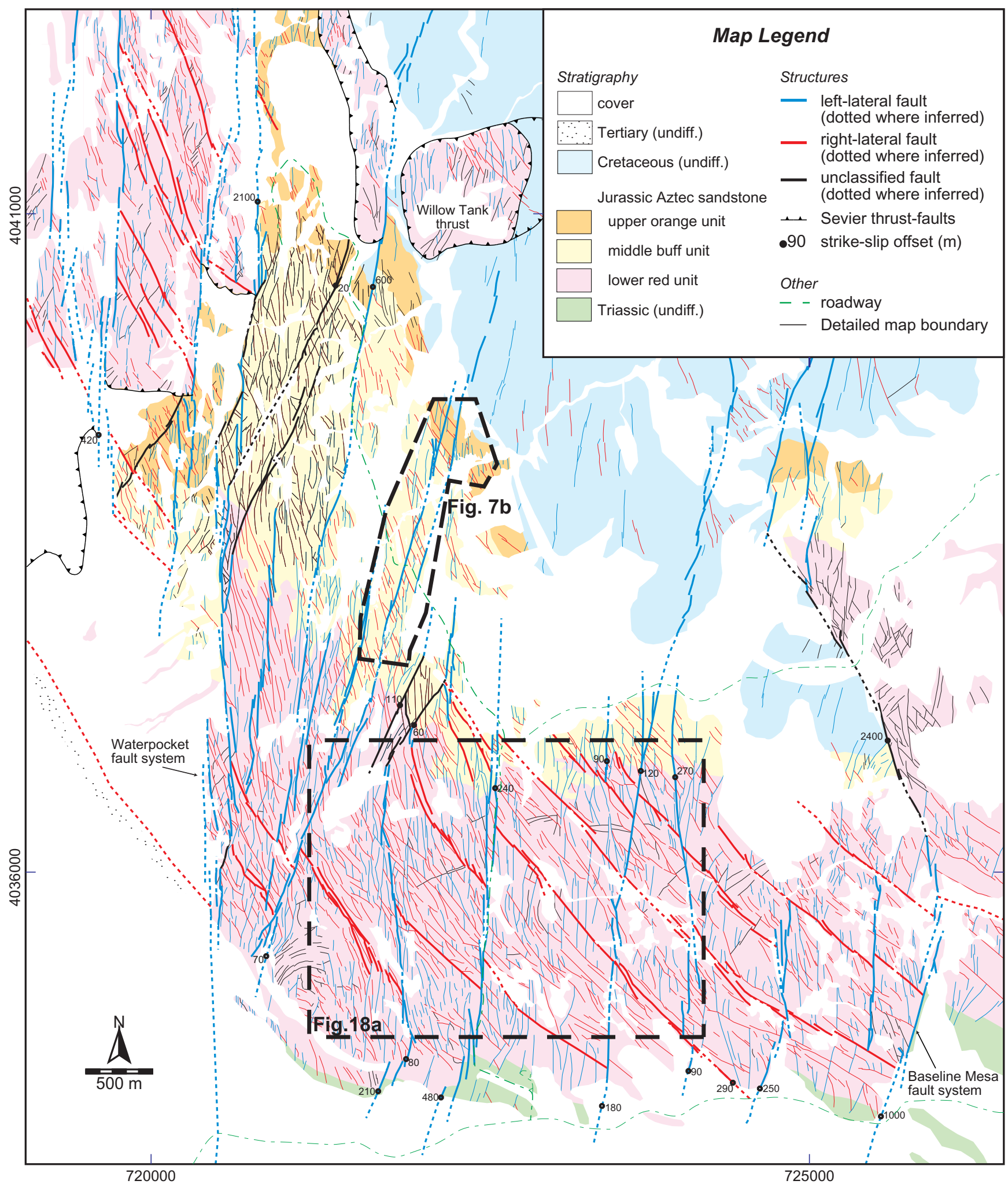

Figure 6. Map (Flodin and Aydin 2004) showing two sets of Tertiary Basin and Range faults with systematic trends: One set slightly east of north (blue) which is predominantly left lateral, and another west of north (red) which is right lateral. The first order left lateral faults bound the second order right lateral faults, which in turn bound the third order left-lateral faults. Note that other faults in different orientations also exist (black). Numbers for lateral slip magnitudes. Areas of detail shown in figures $7 \mathrm{~b}$ and $18 \mathrm{a}$ are denoted by dashed outlines. 
(a)

$100 \mathrm{~m}$

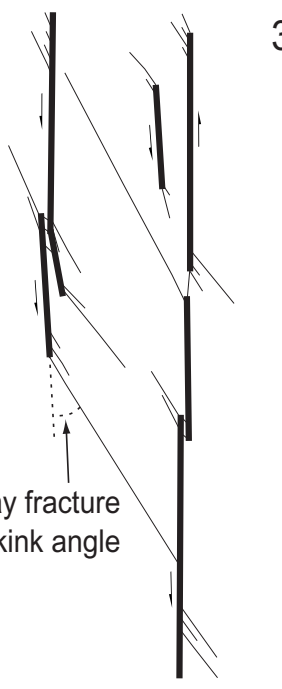

3

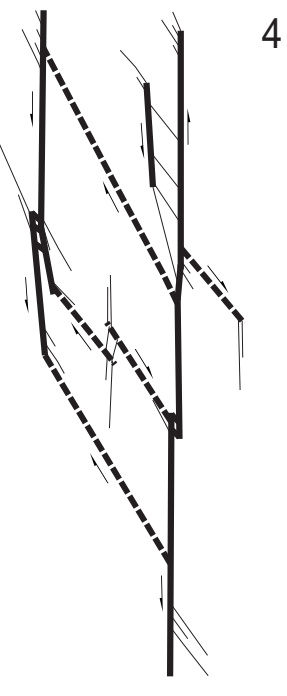

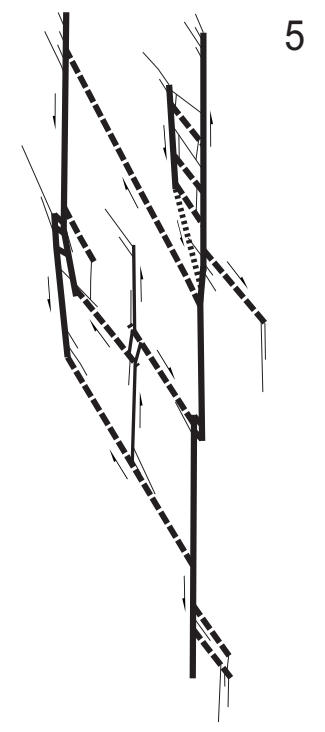

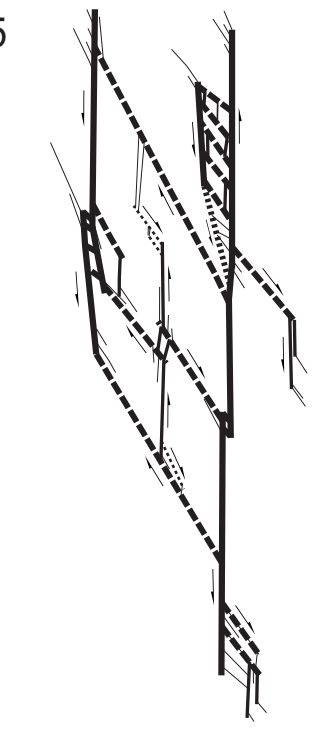

preexisting joint splay fracture

- $3^{\text {rd }}$ generation left-lateral fault ........ $4^{\text {th }}$ generation right-lateral fault

(b)

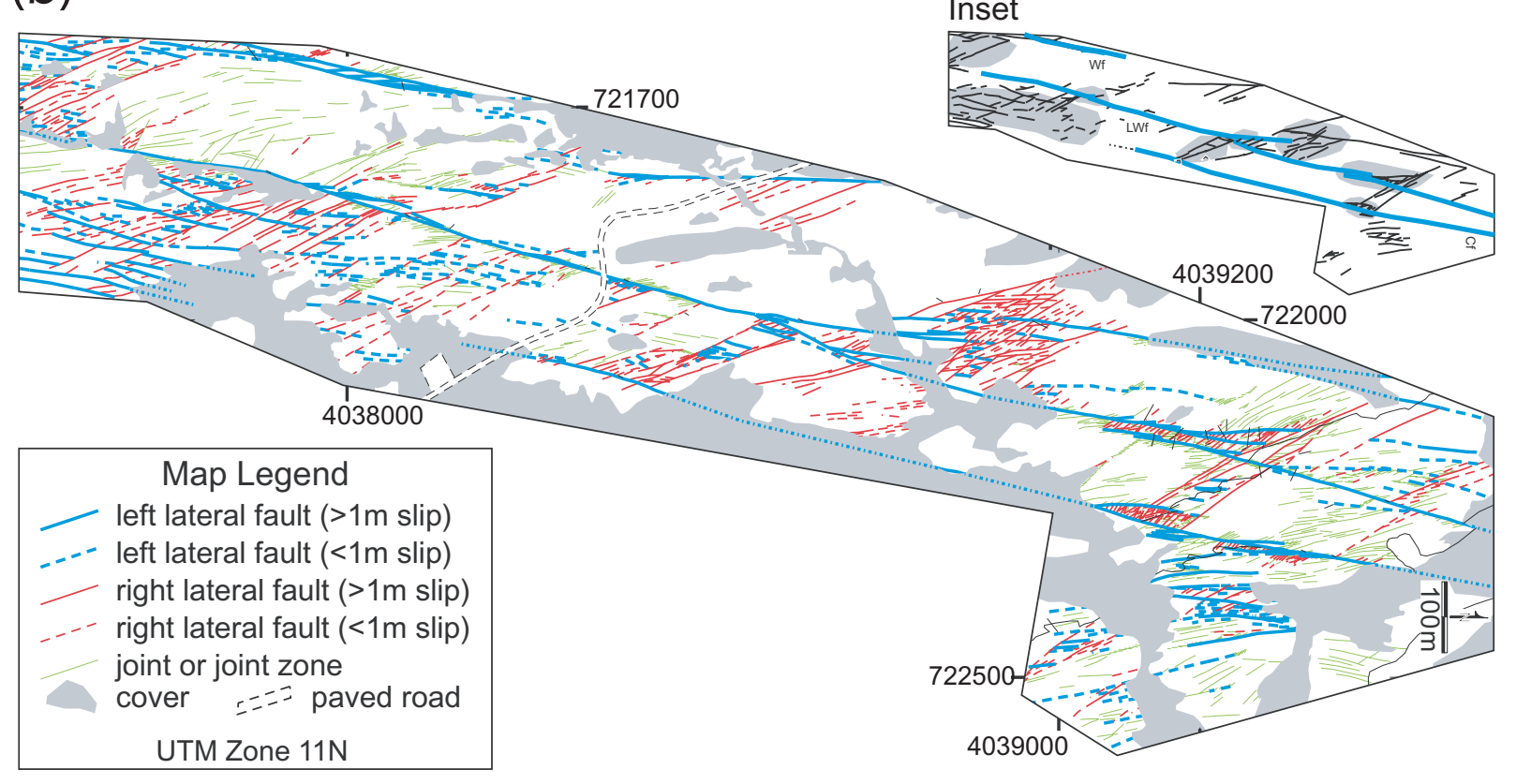

Figure 7. Conceptual model for the evolution of the strike-slip fault network in the Valley-ofFire., Nevada. (a) Preexisting joints prior to, or at the earliest phase of, faulting (1). (2)-(5) Progressive stages of splay fracturing and sequential shearing of splay fractures that evolve into sets of left- and right-lateral faults of various generations. (b) Detailed map of the area boxed in Figure 6 showing the relationship between the segmentation of the first order left lateral faults (solid blue) and the distribution of the second order right lateral faults (red). From Flodin and Aydin 2004. 
We have refined (Flodin et al., 2004) the fluid flow properties of faults formed by shearing of joint zones that we had described in earlier years. The results show that the cross fault permeability is one to three orders of magnitude lower, and breakthrough pressures are one to two orders of magnitude higher than the median host rock permeability and capillary pressure, respectively (Figure 8). Calculated maximum sealable hydrocarbon column heights, using standard fluid properties, range between 10-69 $\mathrm{m}$ of gas, and 17-120 $\mathrm{m}$ of oil. These data suggest that faults formed by shearing of joints in high permeability sandstone systems will act as barriers to fluid flow during production and might be capable of sealing small to moderate hydrocarbon columns on an exploration time-scale, assuming adequate continuity of the fault rock over large areas of the fault.

By analyzing faults with different slip magnitudes, we have been able to produce a relationship between up-scaled fault permeability and fault slip or shear strain (see permeability/slip transform plot in Figure 8) and produce a variable permeability model for the faults studied (Figure 9a and b) (Flodin et al., 2001). We have compared three simulation scenarios with that used in standard oil-field practice in which faults are represented as tunable, single-permeability features. In the simplest model scenario, we find no significant difference in flow response between the two methodologies. The more complex cases, however, displayed significant differences with regard to breakthrough time and liquid production rates (Figure 9c and d). These differences are attributed to the representation of faults with variable slip and the corresponding variable fault -normal and -parallel permeability.

Due to computational limitations, earlier work (Stanford Rock Fracture Project Workshop Volume, 1999) had used a multi-step approach to solve for block-equivalent permeability. Consequently we calculated the permeability of the domain of interest through a series of coarsening grids. Using a new numerical code, we have been able to solve for the bulk permeability in one step, thereby improving the accuracy and efficiency of the calculations (Jourde et al, 2002).

In an effort to further refine fault zone upscaling practices, we investigated the impact of several different local boundary conditions on the calculated equivalent permeability (Flodin et al., 2004). Pressure - no flow (Figure 10), periodic, and mirror-periodic boundary specifications were considered. The resulting coarse scale permeability tensors are shown to be highly dependent on the local boundary conditions used in the models. We have determined that the use of periodic boundary conditions is inappropriate for modeling rock with fractures that are continuous over length scales greater than the domain of interest. In cases with through-going high permeability features, such as slip surfaces, the use of pressure-no flow boundary conditions retains fracture-flow continuity and better reflects the field observation. Periodic boundary conditions, by contrast, are more suitable for systems lacking through-going high permeability features. This sensitivity to boundary conditions calls into question the robustness of the equivalent permeability for the general case and suggests that dominant through-going 
(a)

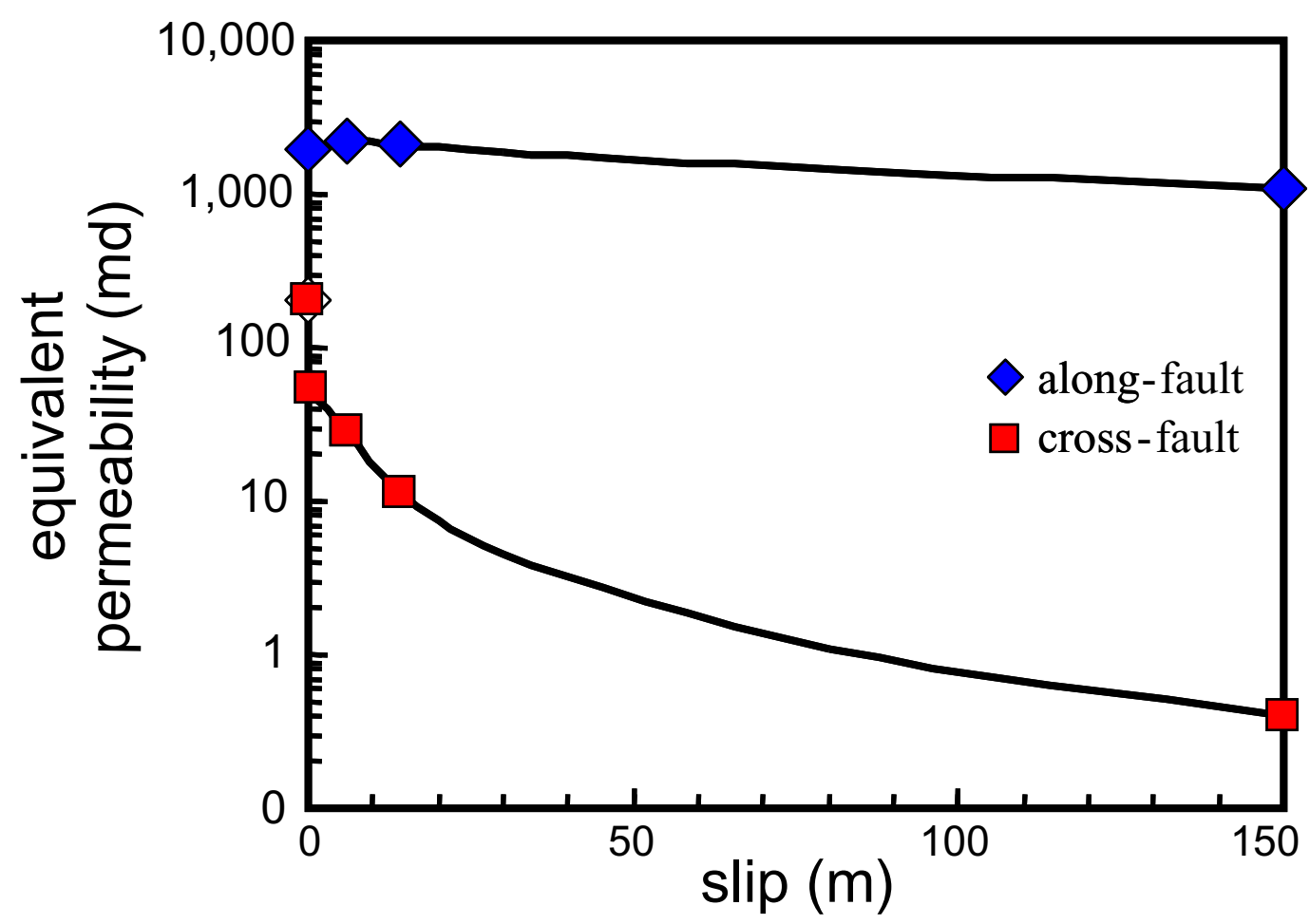

(b)

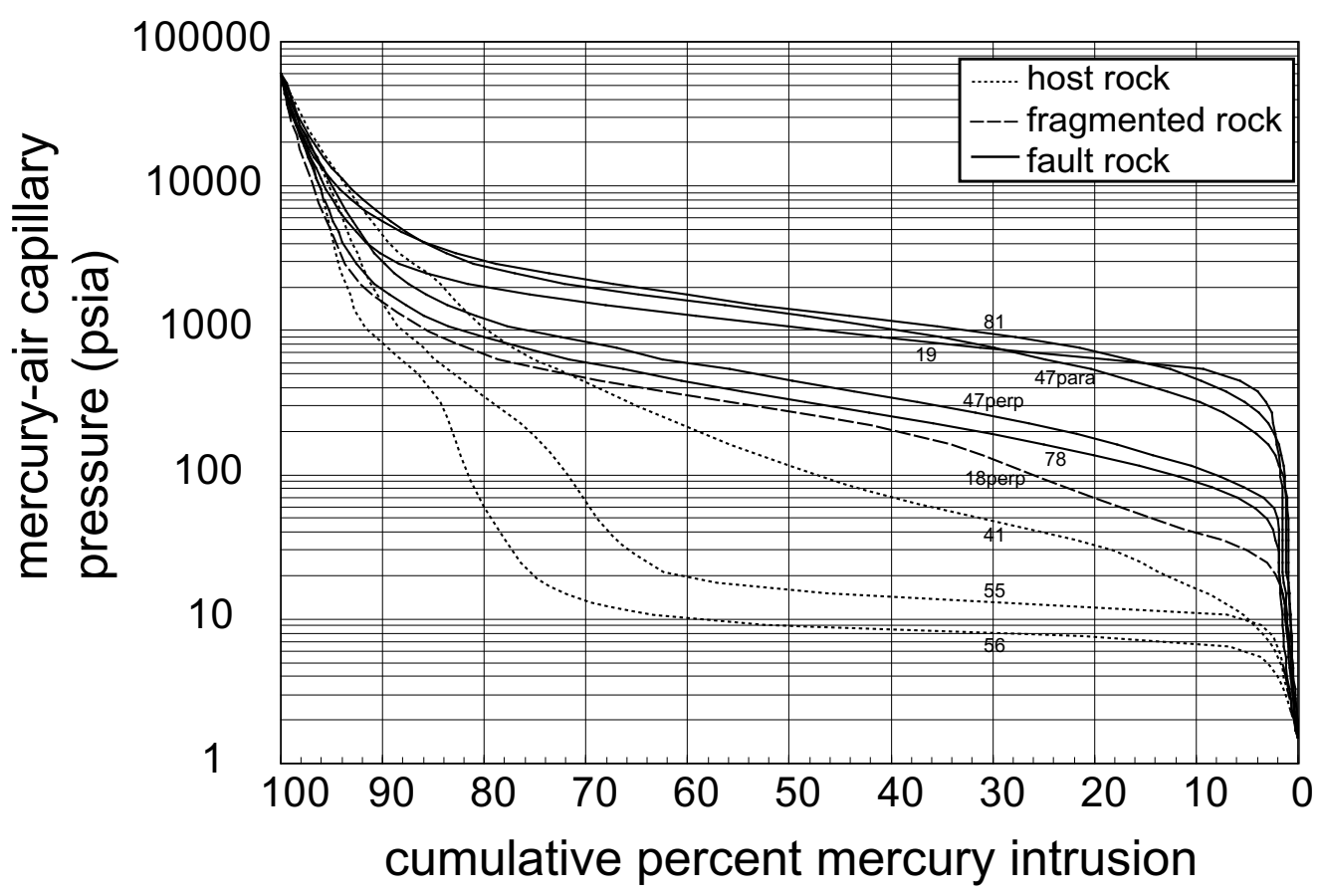

Figure 8. (a) Permeability/slip transformer. Equivalent cross - fault permeability is 1 to 3 order of magnitude smaller than that of the undeformed rock permeability. (b)Capillary pressure versus cumulative percent intrusion for select samples of host rock (dotted line), fragmented rock (dashed line), and fault rock (solid line). Sample numbers are also shown. The mercury-air capilary pressure for the fault rock is one to two order of magnitude higher. These results indicate that similar faults in the subsurface should be capable of trapping small to medium heights of hydrocarbon columns (from Flodin et al. 2001, and Flodin et al. 2004-in press. 
(a)

along-fault permeability $\left(\mathrm{k}_{\mathrm{yy}}\right)$
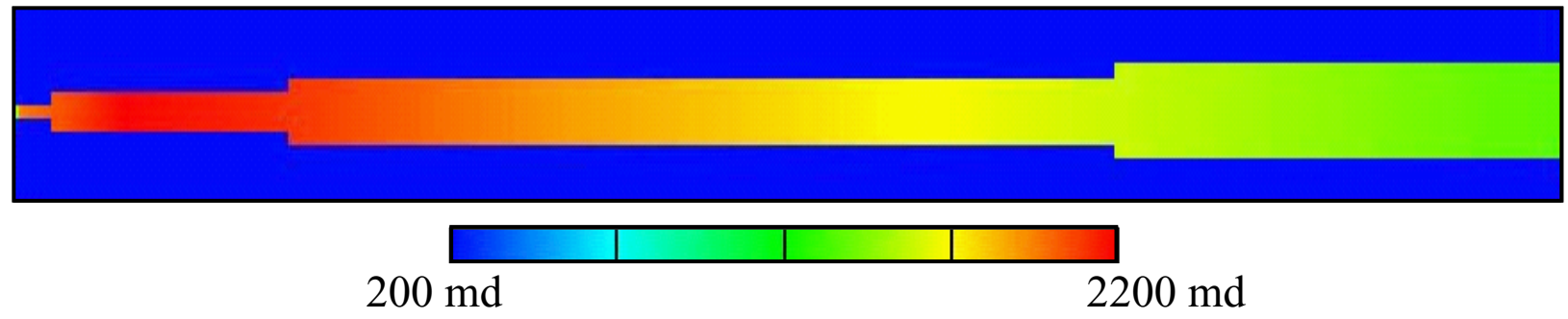

(b) cross-fault permeability $\left(\mathrm{k}_{\mathrm{xx}}\right)$
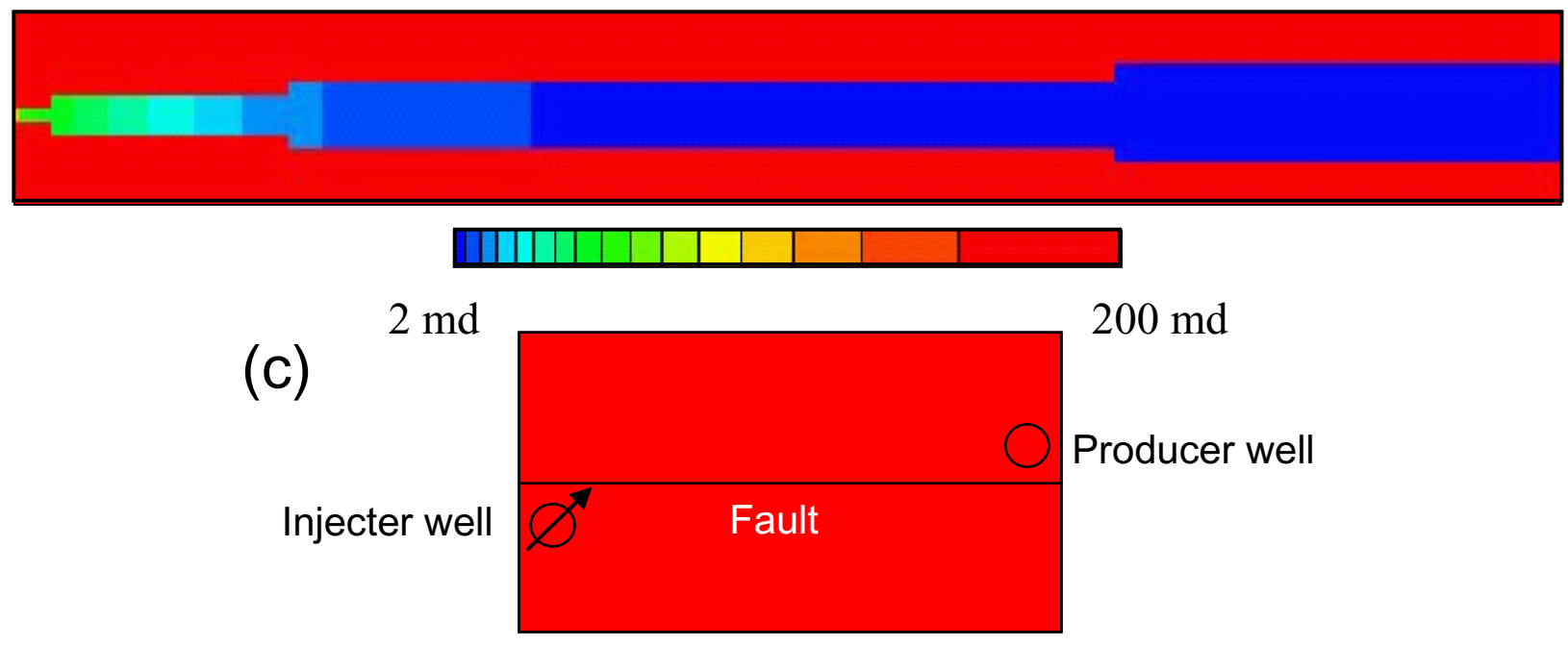

(d)

variable $k$

Oil profiles at 90 days
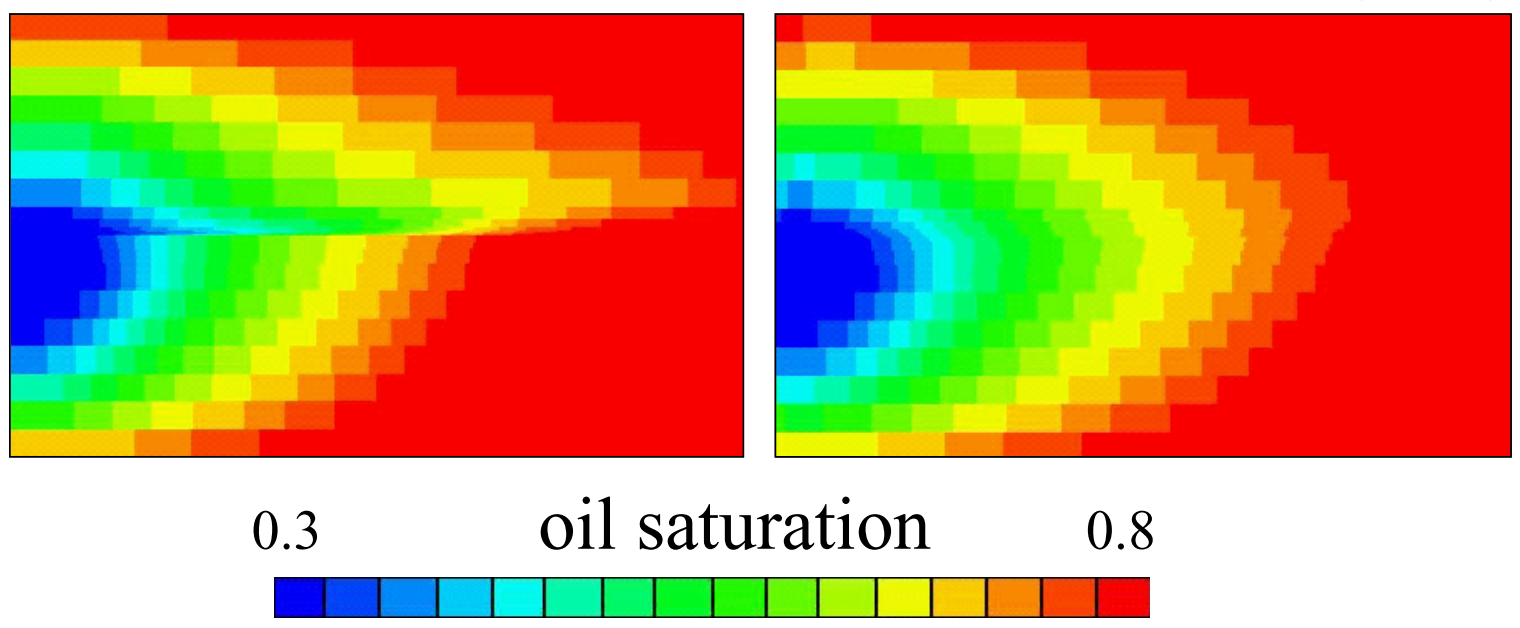

Figure 9. (a) and (b) Fault permeability populated using permeability/slip transformer in Figure 2 for fault half-length only. Note that both maps have a 15' vertical exaggeration. (c) Peripheral injector/producer wells and (d) oil saturation profiles for the peripheral wells and comparison with that for the constant permeability case. The profles indicate significant differences for using variable and constant permeabilities (Flodin et al. 2001). 


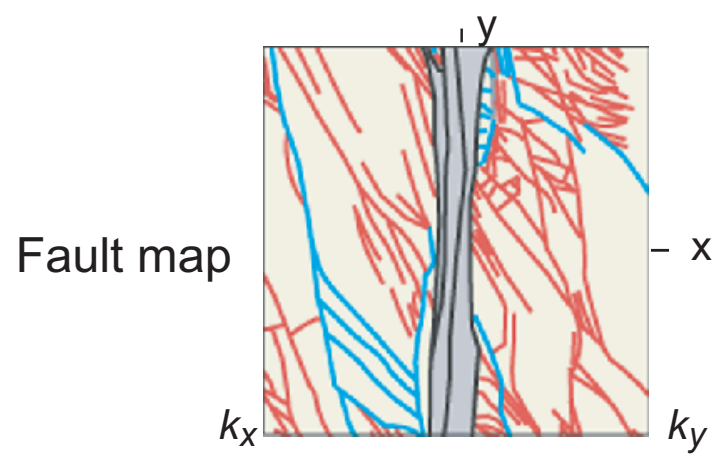

(a) $50 \times 50$
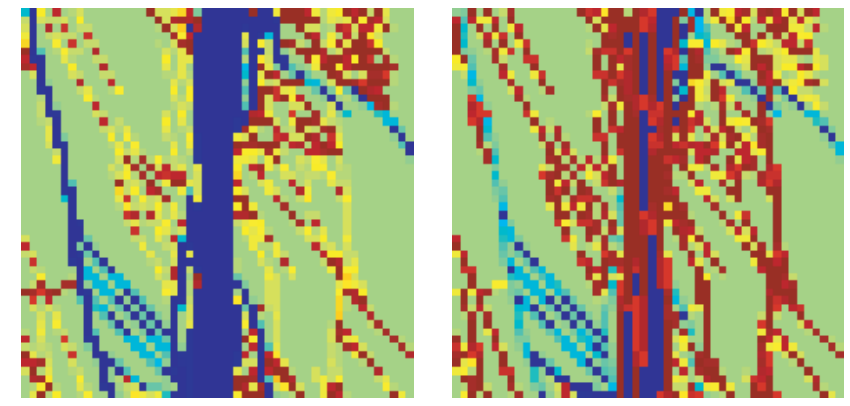

(b) $30 \times 30$
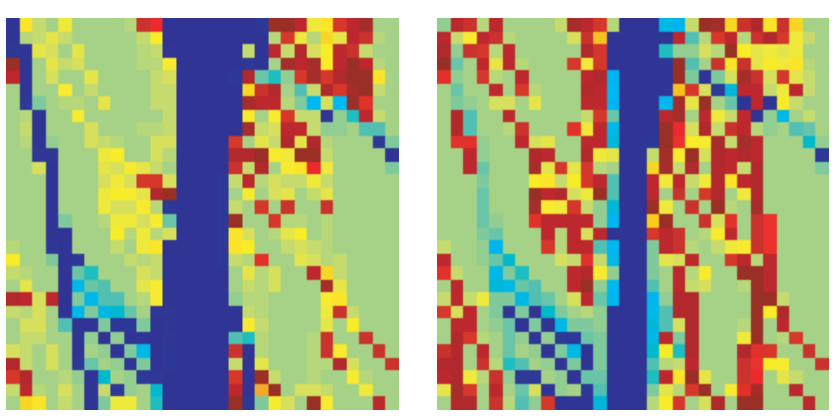

(c) $10 \times 10$
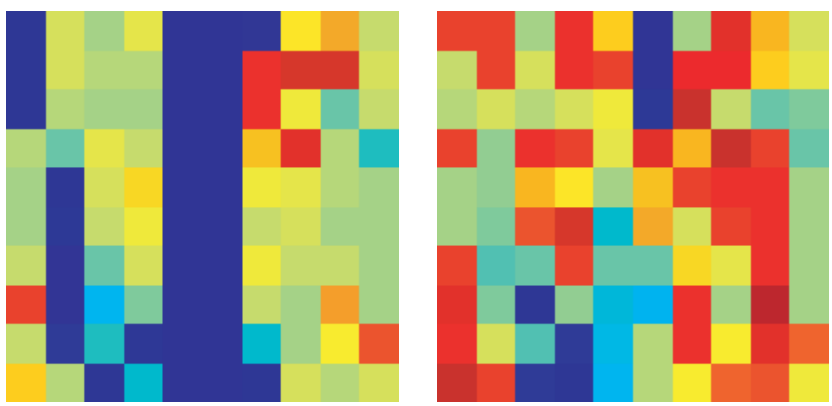

Ink

(d) $3 \times 3$
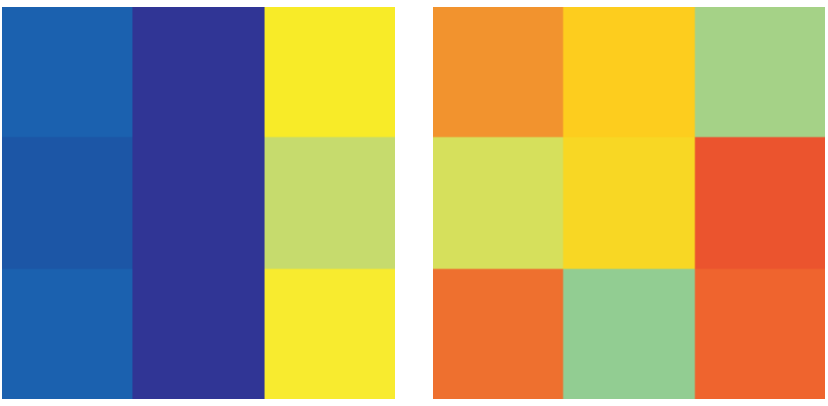

Figure 10. Upscaling results using local pressure - no-flow boundary conditions and the input fault map (top). Finer block size from bottom to top. Fault parallel permeability, ky is enhanced whereas cross fault permeability, $\mathrm{k}_{\mathrm{x}}$, is reduced (from Flodin et al., in press). 
features would best be modeled explicitly. Furthermore, due to the very small thickness and high permeability of some through-going structural features (for example, slip surfaces), globally upscaled models are inadequate for the modeling of transport. To address these issues, a "partial upscaling” method that entails removing the through-going high-permeability features, such as slip surfaces, from the fine model, upscaling to a coarse grid, and then reintroducing the highpermeability features back into the coarsened model, is adopted. This procedure is shown to provide coarsened models that give accurate predictions for both flow and transport.

\section{Mechanical characterization of compaction bands and their effect on bulk permeability}

This research sub-project has been motivated by the results of studies which demonstrate the potential for low-permeability deformation bands (DBs) to impede fluid flow through otherwise highly transmissive sandstone (Jourde et al., 2002; Taylor and Pollard, 2000; Myers and Aydin, 2004;). We have developed a methodology for calculating effective permeability tensors for twodimensional networks of DBs using established numerical techniques (Sternlof et al., 2004). The method, derived from homogenization theory, can produce effective permeability values for any DB pattern, and provides a quantitative framework with which to upscale these results from spatially limited data for repetitive patterns. We have applied the method to each of three characteristic outcrop-scale DB patterns exposed in the Aztec Sandstone at the Valley of Fireparallel, cross-hatch and anastomosing. Our work indicates that these systematic band patterns can reduce effective permeability by as much as two orders of magnitude, while inducing similar magnitudes of permeability anisotropy (Figure 11). The impact of DB arrays on intrinsic sandstone permeability thus rival those attributed to depositional features (e.g. bedding and shale streaks) and commonly accounted for in reservoir/aquifer flow simulations.

The potentially profound impact of DB arrays on bulk sandstone permeability led us naturally to three fundamental research questions: (1) Do DB arrays in fact influence permeability on the reservoir/aquifer production scale; (2) By what mechanism(s) and under what geologic conditions do they form; and (3) Can we learn to forecast their presence and geometry in the subsurface based on limited data? To address these questions, we have been pursuing three complementary research initiatives: field and petrographic characterization; elasticity-based, computer-aided numerical simulation; and laboratory experimentation.

Our field work indicates that thick $(\sim 1 \mathrm{~cm}+)$, high-angle-to-bedding compaction bands (CBs) — which exhibit limited primary shearing — constitute the volumetrically dominant DB type present throughout the bleached portion of the middle to upper Aztec. These occur in two distinct orientation sets- NNW trending, steeply E dipping and SSW trending, steeply W

dipping - that are generally at high angle to each other $\left(80^{\circ}\right.$ to $\left.90^{\circ}\right)$ and interact to form the three characteristic outcrop patterns which together comprise the oldest structural fabric present. The density, distribution and continuity of these CB patterns strongly suggest an ability to influence 

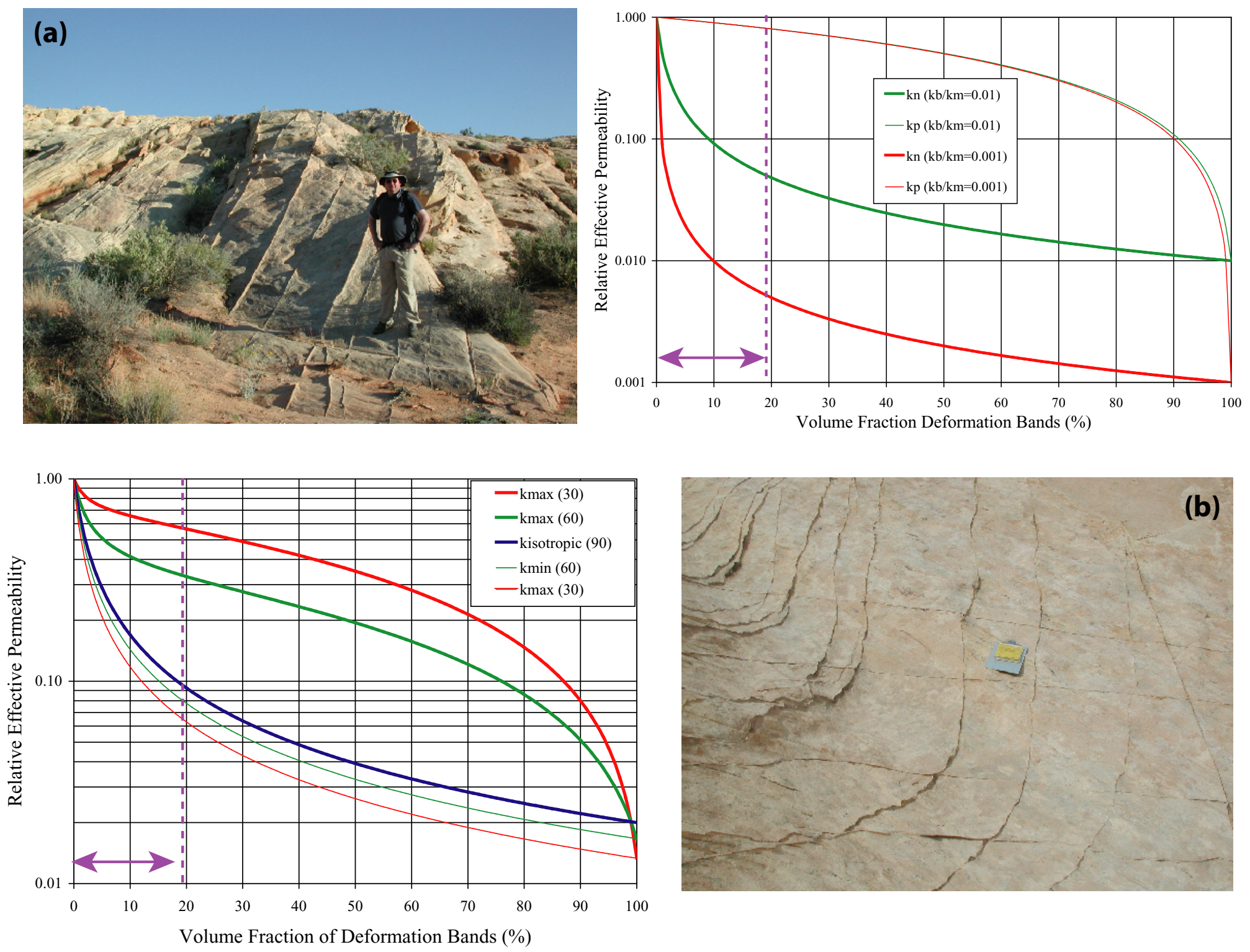

Volume Fraction of Deformation Bands (\%)
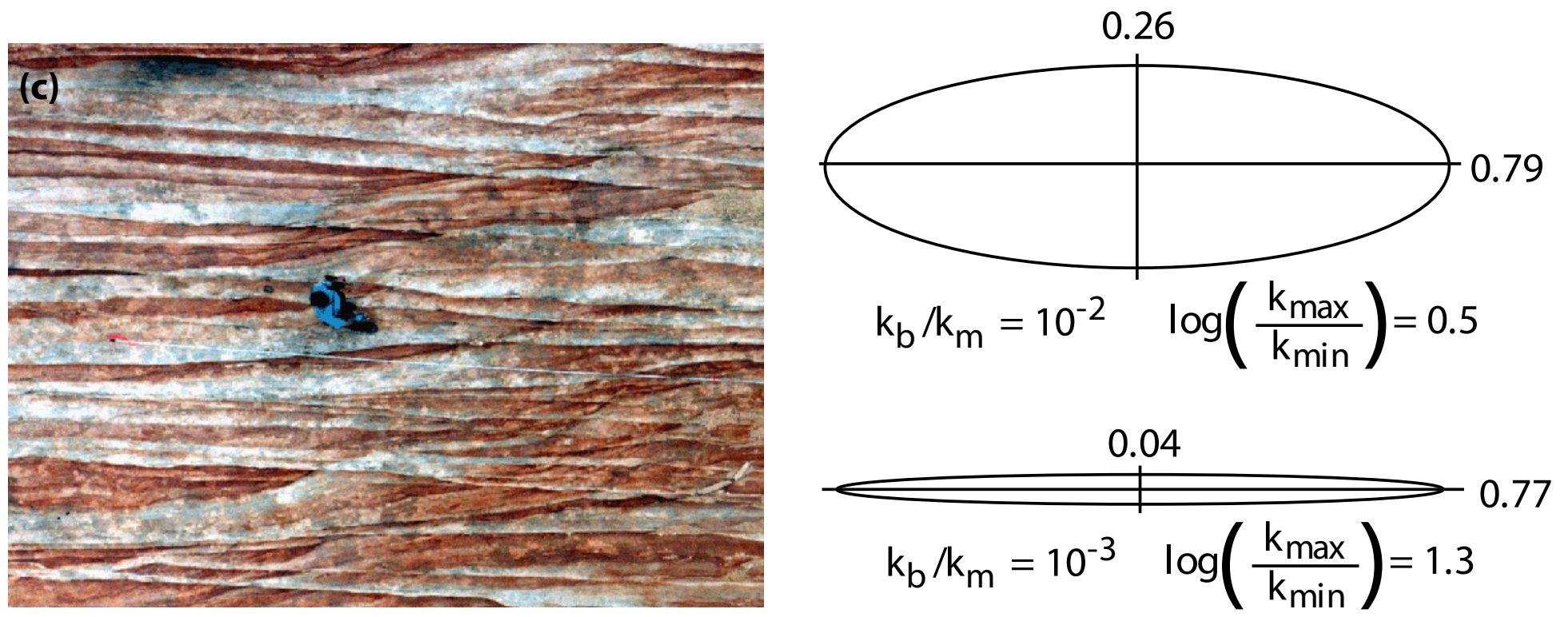

Figure 11. Two-dimensional permeabilty effects of the characteristic compaction band patterns in the Aztec Sandstone. (a) Parallel pattern--relative band-normal $(\mathrm{kn})$ and band-parallel $(\mathrm{kp})$ effective permeability plotted versus band volume fraction for band/matrix permeability ratios $(\mathrm{kb} / \mathrm{km})$ of 0.01 and 0.001 . Purple arrow denotes realistic volume fraction range. (b) Cross-hatch pattern--relative principal effective permeability for $\mathrm{kb} / \mathrm{km}=0.01$ plotted versus band volume fraction for intersection angles of 30,60 and 90 degrees (realistic band volume fraction range indicated in purple). (c) Anastamosing pattern--relative effective principal permeability ellipses calculated for the specific pattern pictured and kb/km ratios of 0.01 and 0.001 . 
permeability and flow at production scales (Figure 12). A third group of DBs, which tend to be bedding parallel and often exhibit $\mathrm{mm}$ to $\mathrm{cm}$ shear offsets, overprint the CBs.

Petrographic analysis reveals that the CBs accommodate porosity loss compaction via granular rearrangement with limited comminution. The total volume loss due to compaction across a band is about $10 \%$ (from $\sim 25 \%$ to $~ 15 \%$ porosity), equivalent to about $1 \mathrm{~mm}$ of closing mode displacement per cm of CB thickness. Subsequent preferential accumulation of clays has led to residual CB porosities of $<10 \%$ (Figure 13), greatly enhancing their ability to impede fluid flow. We have collected 20 tip-to-tip thickness profiles of CBs ranging in trace length up to 62 $\mathrm{m}$. Interpreting thickness as a direct proxy for closing mode displacement reveals a marked correspondence between CBs and idealized elastic anticracks (Figure 14). We now advocate a conceptual and mechanical model of CBs as modified anticracks, which initiate, propagate and interact to form systematic patterns in pre-lithified sand subjected to regional tectonic compression (Sternlof and Pollard, in preparation).

Currently, we have developed a numerical boundary element computer code based on elasticity theory and using MATLAB ${ }^{\circledR}$ to simulate $\mathrm{CB}$ propagation and pattern development. This tool will enable us to test and refine the modified anticrack model by comparing simulated patterns derived with realistic material parameters and remote boundary loads to natural patterns observed in outcrop. Preliminary efforts already have yielded some promising results, although much work remains to be done given the computational complexity of the task. Ultimately, computer-aided numerical simulation will greatly enhance our ability to interpret the paleotectonic significance of a given $\mathrm{CB}$ pattern and, conversely, to forecast the presence and geometry of subsurface CB arrays based on knowledge of key material parameters and geologic loading histories.

We also have embarked on a program of laboratory experimentation in collaboration with Drs. William Olsson and David Holcomb at Sandia National Laboratory, Dr. Bezalel Haimson at the University of Wisconsin, and Dr. David Lockner at the U.S. Geological Survey in Menlo Park, CA. Although experimental research into compaction localization in sandstones has blossomed over the past several years (e.g. Haimson and Kovacich, 2003; Haimson, 2001; Wong et al., 2001; Olsson and Holcomb, 2000; Olsson, 1999) we recognized that compaction features commonly being produced in the lab bear little resemblance to natural CBs at the Valley of Fire. We believe this shortcoming to be primarily a consequence of experimental design - wellcemented, strong sandstones subjected to mid-crustal confining pressures of 100 to $300 \mathrm{MPa}$ without benefit of a starter flaw to initiate failure away from the steel endcap/specimen interface. Using our starter-flaw idea, Drs. Teng-fong Wong and Veronika Vajdova at SUNY Stony Brook have succeeded in producing discrete compaction features in circumferentially notched specimens of Bentheim Sandstone (Vajdova et al., 2003), albeit at more than 250 MPa confining pressure. 


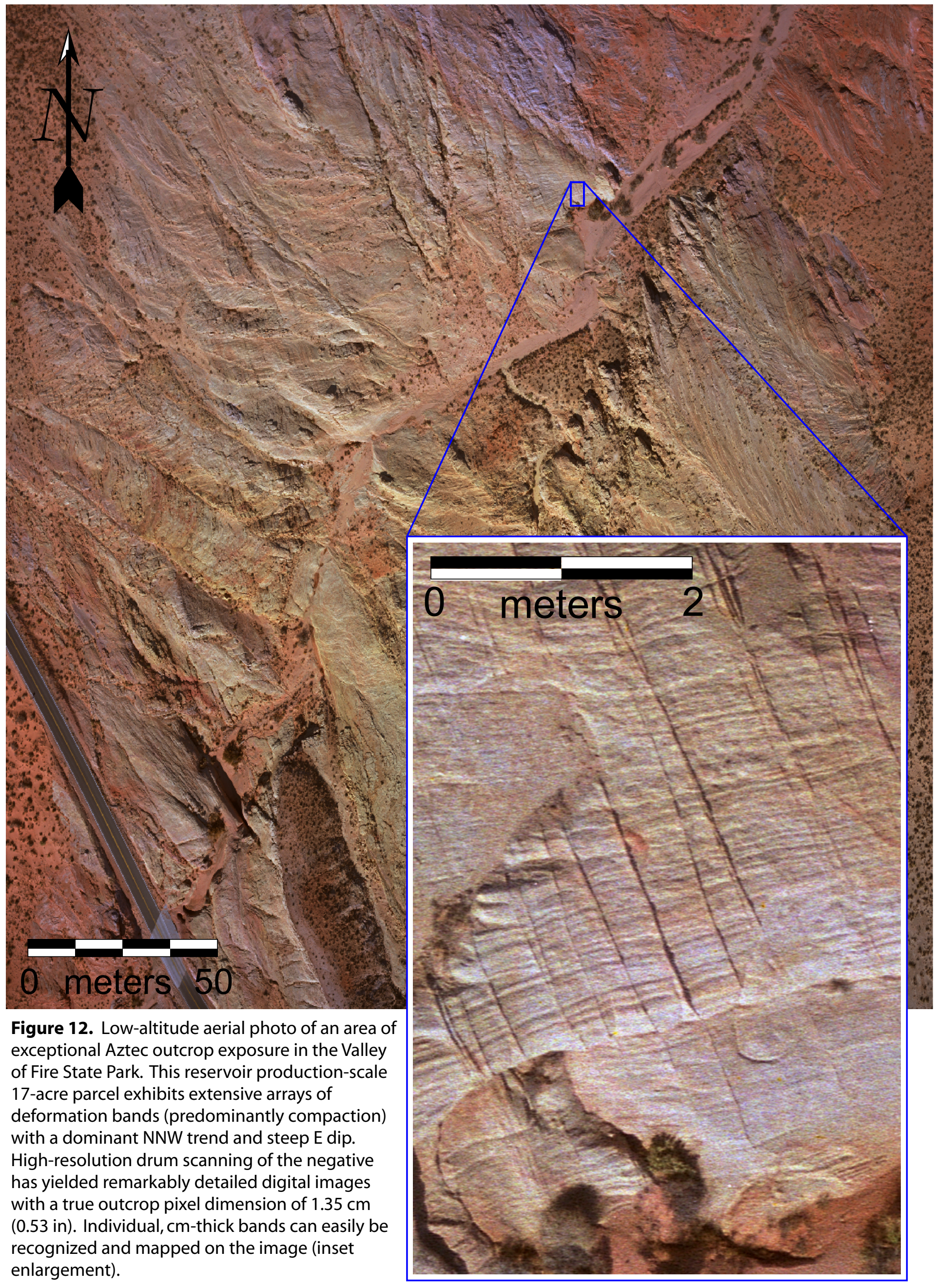


(a)

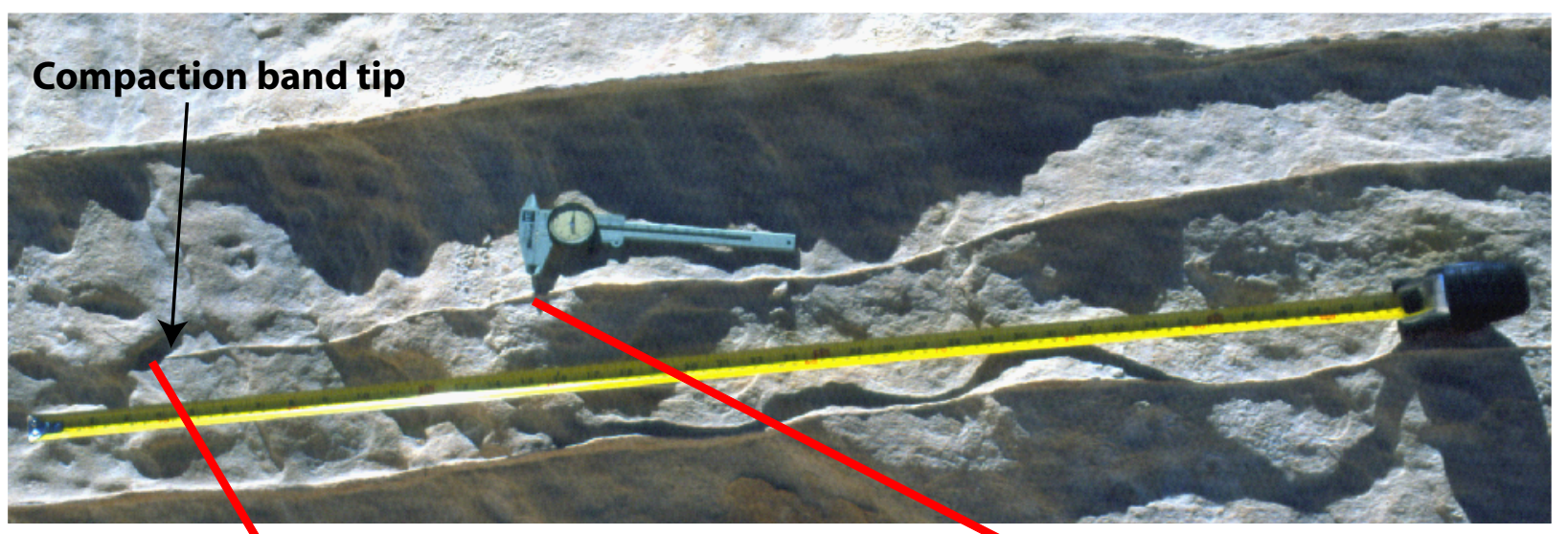

(b)
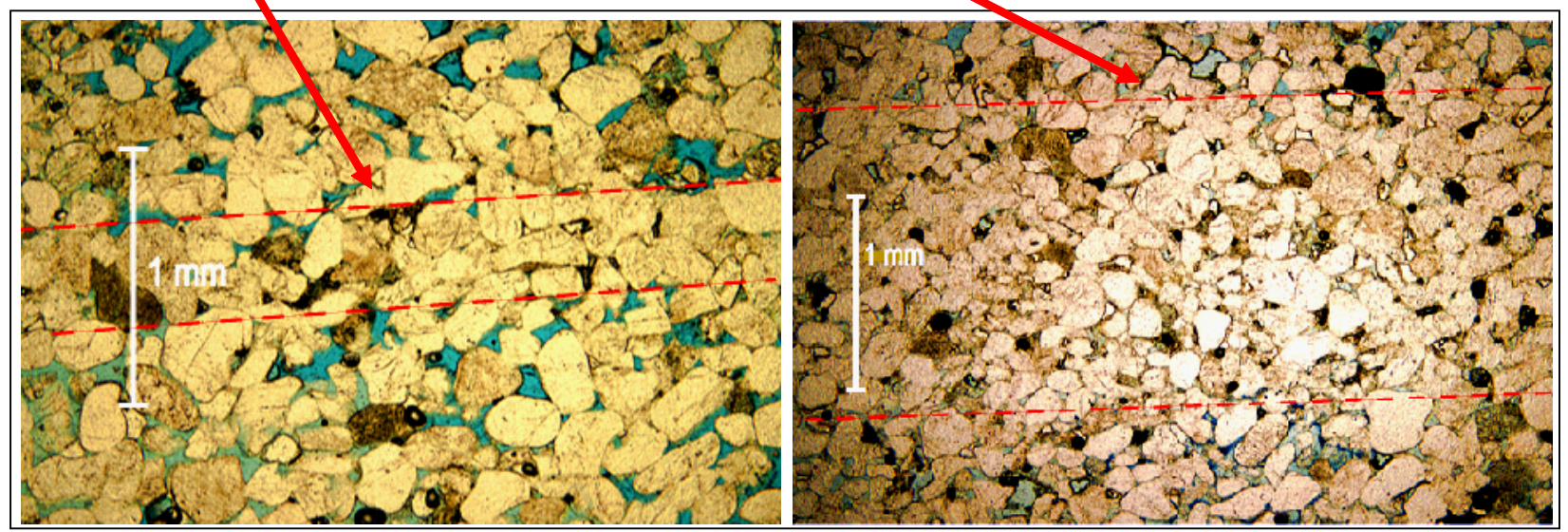

(c)
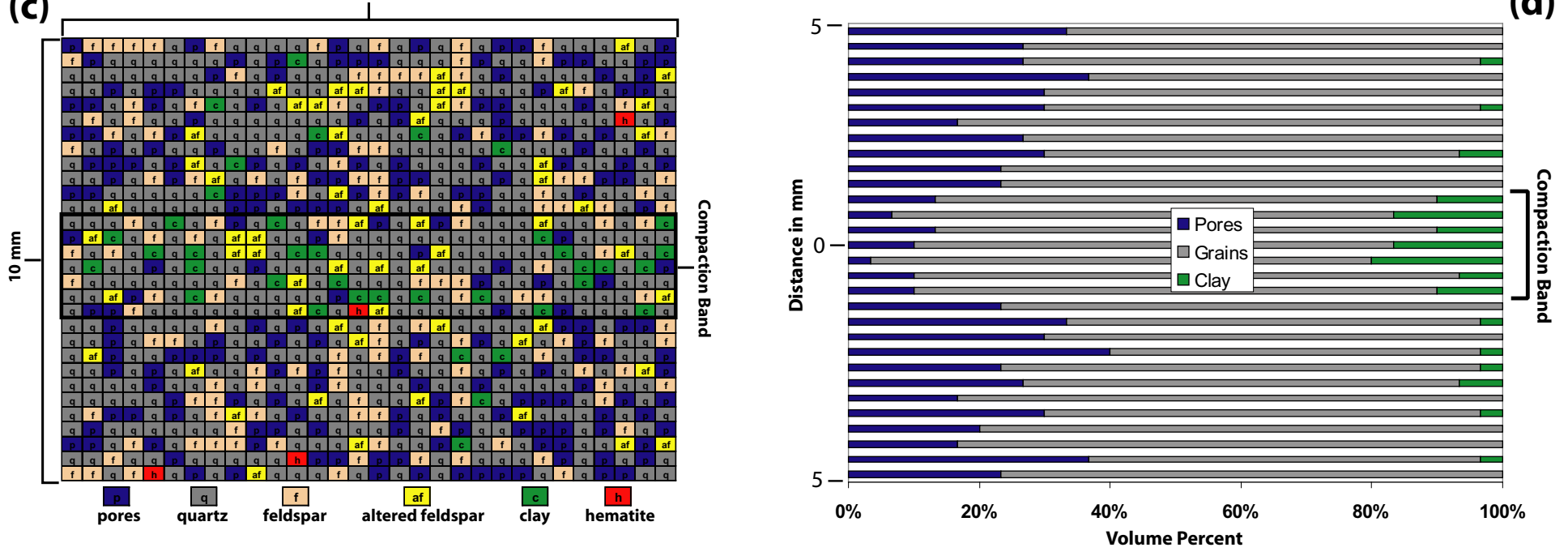

(d)

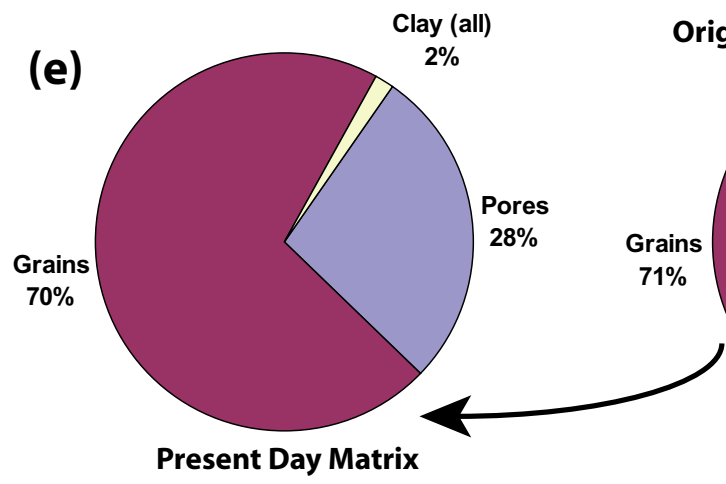

Original Depositional Sandstone

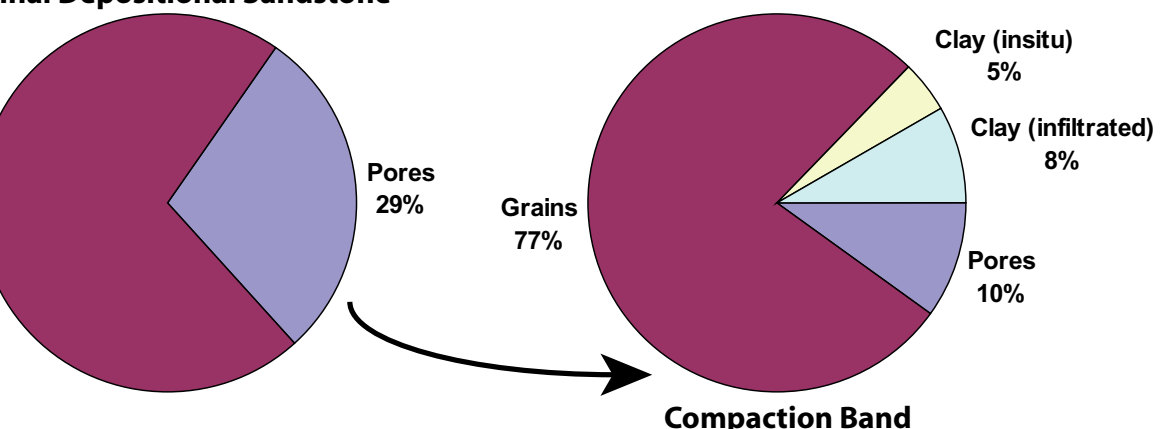

Figure 13. Petrographic analysis of compaction bands. (a) Typical morphology of thick compaction bands in outcrop (note tip). (b) Photomicrographs illustrating porosity loss within the band accommodated by granular rearrangement and limited comminution. Dashed red lines denote approximate band boundaries, blue green is pore-filling epoxy. (c) Point-counting analysis across representative band. Blue squares represent porosity. (d) Stacked bar graph showing distribution of pores, detrital grains and clay from data in (c). (e) Schematic representation of compaction bands versus general sandstone matrix as evolved from the original depositional Aztec. Clay (in situ) refers to direct alteration products from feldspar within the band; Clay (infiltrated) refers to material deposited by migrating fluids. Net compactive pore-loss volume reduction is thus about $10 \%$. 

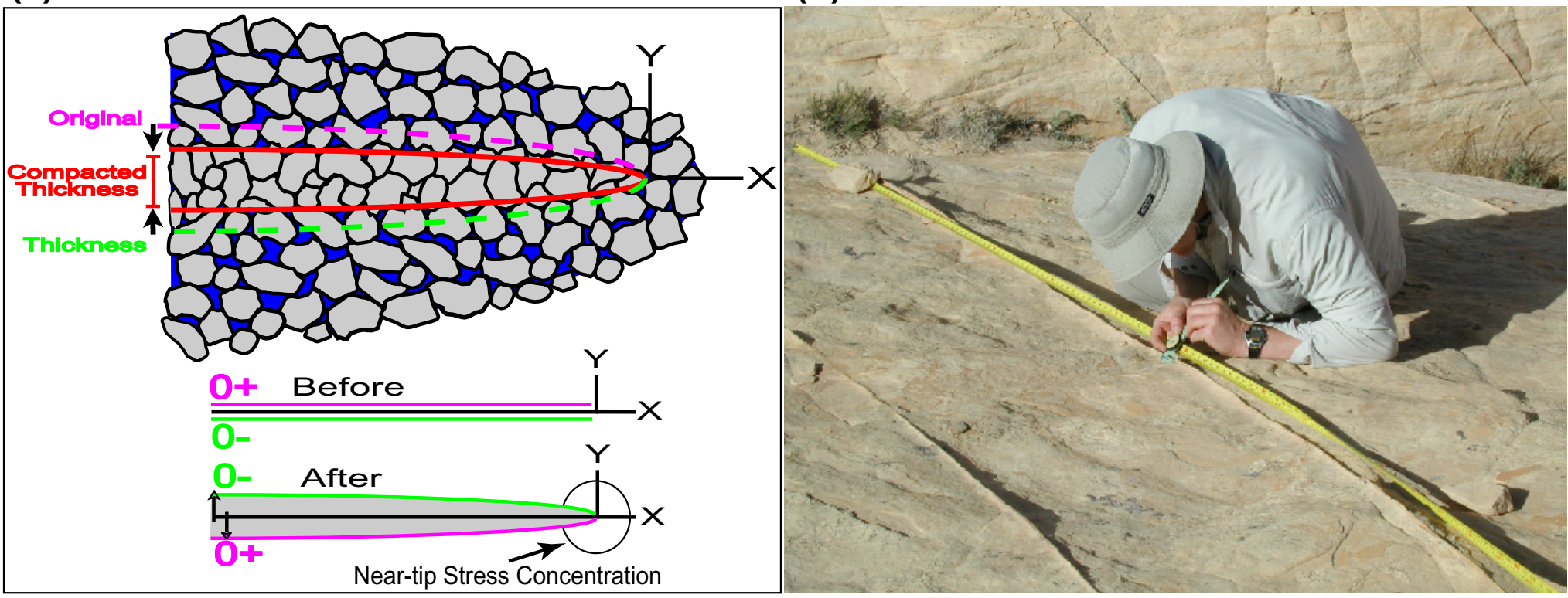

(c)

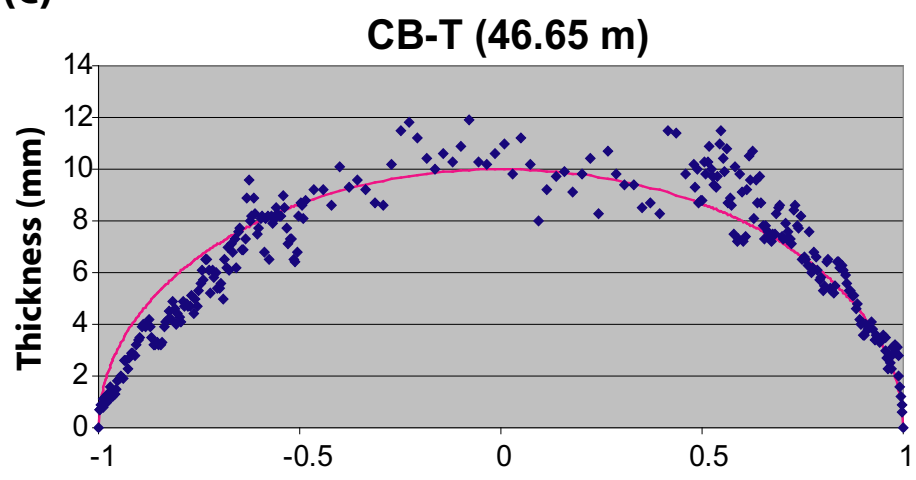

Position normalized by half-length
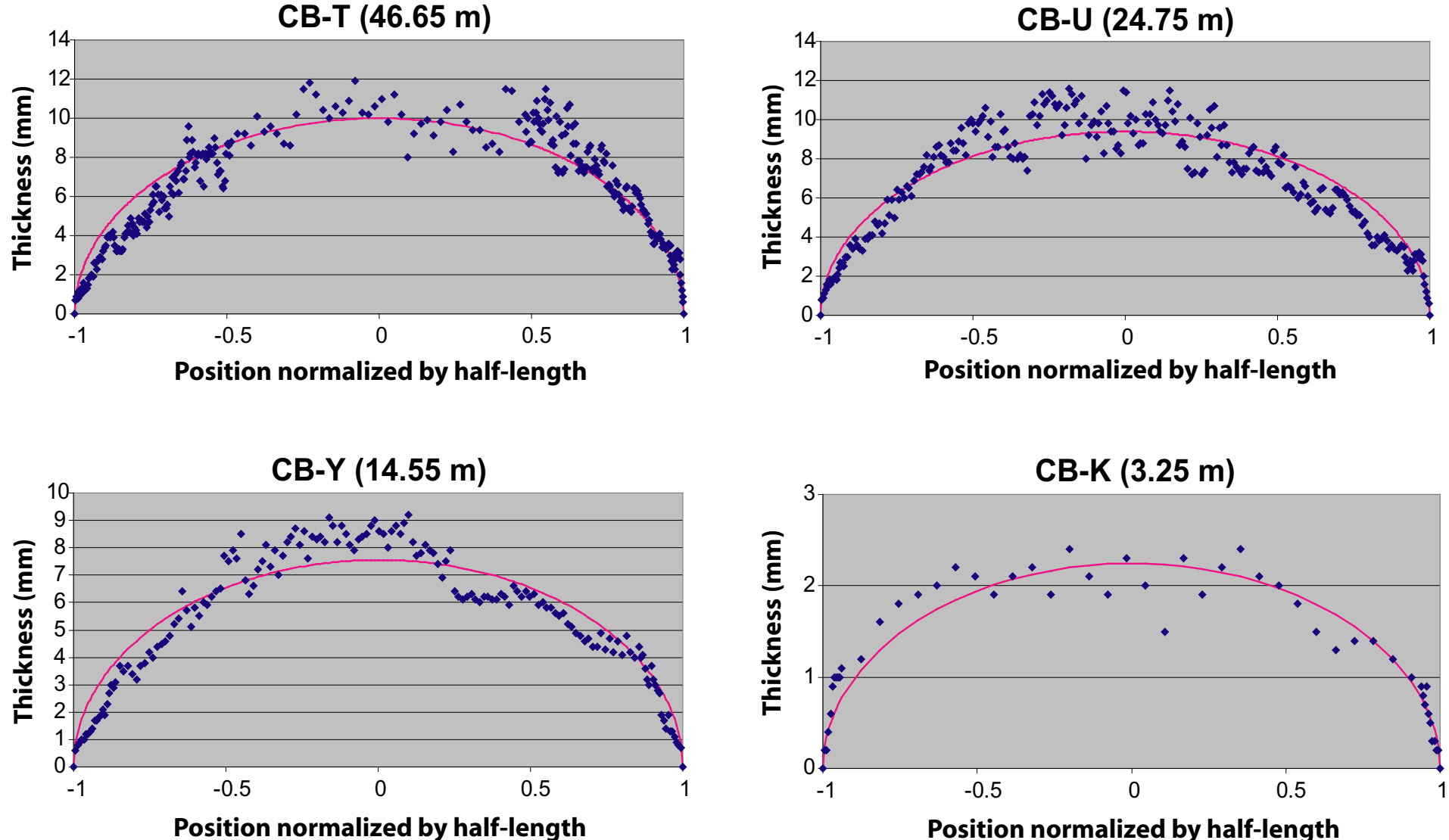

Figure 14. (a) Conceptual anticrack model in 2-D assuming pure porosity loss compaction and plane strain. As the grains compact, the imaginary boundary around them (purple and green dashed lines) moves inward to coincide with the physical boundary of the final band (red line). This inward displacement can be represented as the interpenetration of the imaginary, precompacted band boundaries by an amount equivalent to the net porosity loss. The resulting distribution of closing mode displacement induces an anticrack near-tip stress field. (b) Collecting compaction band thickness profiles in the Valley of Fire. Petrographic analysis indicates that the degree of compaction is fairly uniform within a given band from tip to middle, suggesting band thickness as a reasonable first-order proxy for closing mode displacement. (c) Tip-to-tip thickness/closing mode displacement profiles for representative compaction bands plotted versus normalized trace half-length. The purple curves indicate best-fit distributions of closing mode displacement generated by a simple, elastic anticrack model. The goodness of fit between the field data and model predictions support our mechanical interpretation of compaction bands as anticracks. 
Meanwhile with our collaborators at Sandia, Wisconsin and Menlo Park, we have attempted a number of both standard and true triaxial compression experiments on weakly cemented Aztec specimens ( $<3 \mathrm{MPa}$ unconfined uniaxial compressive strength) using various starter flaw configurations and relatively modest confining pressures. Although these 'proof-of-concept' experiments have as yet failed to produce CB-like compaction localization (Figure 15), we remain convinced that the problem lies with our experimental design rather than the modified anticrack model itself, which is firmly rooted in field observation. In particular, we suspect that even the modern Aztec has become too well lithified to allow compaction band failure to occur, and so we currently are designing new experiments that will test unconsolidated sand specimens with built-in central flaws subjected to low, near-surface confining pressures.

\section{Broader Implications of the Results}

Fractures and faults exert critical impacts on fluid flow in rocks, with relevance to many problems including aquifer and reservoir management, safe repository site characterization, and $\mathrm{CO}_{2}$ sequestration as part of the solution to this pressing environmental problem. The research reported here contributes to a sound, process-based understanding of the formation of fractures and faults in sandstone, and of their physical and chemical impacts on fluid flow.

\section{PUBLICATIONS SUPPORTED UNDER THIS PROJECT}

\section{Refereed Journal Papers}

Flodin, E., Aydin, A., Durlofsky, L. J., and Yeten, B., 2001, Representation of Fault Zone Permeability in Reservoir Flow Models, SPE paper\# 71617, p. 1-10.

Jourde, H., Flodin, E., Aydin, A., Durlofsky, L., and Wen, X. H., 2002, Computing Permeability of Fault zones in Aeolian Sandstone From Outcrop Measurements. AAPG Bulletin, v. 86, No. 7, p. 1187-1200.

Lore, J. S., Eichhubl, P., and Aydin, A., 2002, Alteration and fracturing of siliceous mudstone during in situ combustion, Orcutt field, California. J. Petroleum Sciences and Engineering, v. 36, p. 169-182.

Du Bernard, X., Eichhubl, P., and Aydin, A., 2002, Dilation Bands: A New Form of Localized Failure in Granular Media. Geophysical Res. Letters, v. 29, no. 24, 2176, 1029/2002GLO15966.

Eichhubl, P., and Aydin, A., 2003, Ductile Opening-mode Fracture by Pore Growth and Coalescence During Combustion Alteration of Siliceous Mudstone. J. Structural Geol., v. 25, p. 121-134.

Flodin, E. A. and Aydin, A., 2004, Evolution of a strike-slip fault network, Valley of Fire, southern Nevada. Geological Society of America Bulletin, v. 116, no. 1/2, p. 42-59, DOI 10.1130/B25282.1.

Flodin, E. A. and Aydin, A., 2004, Faults with asymmetric damage zones in sandstone, Valley of Fire State Park, southern Nevada. Journal of Structural Geology, v. 26, p. 983-988. 
(a)

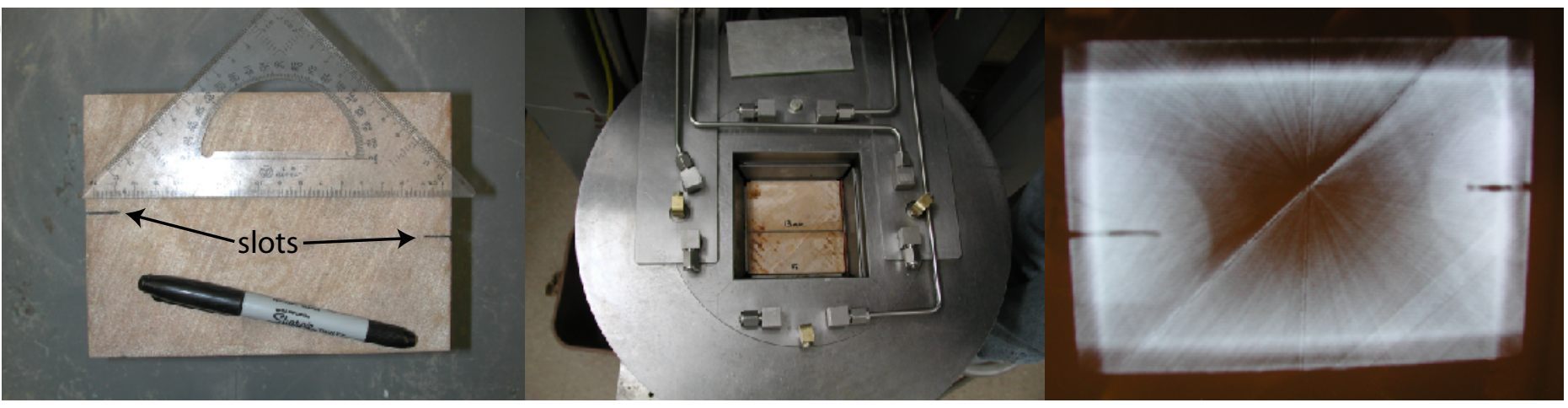

(b)

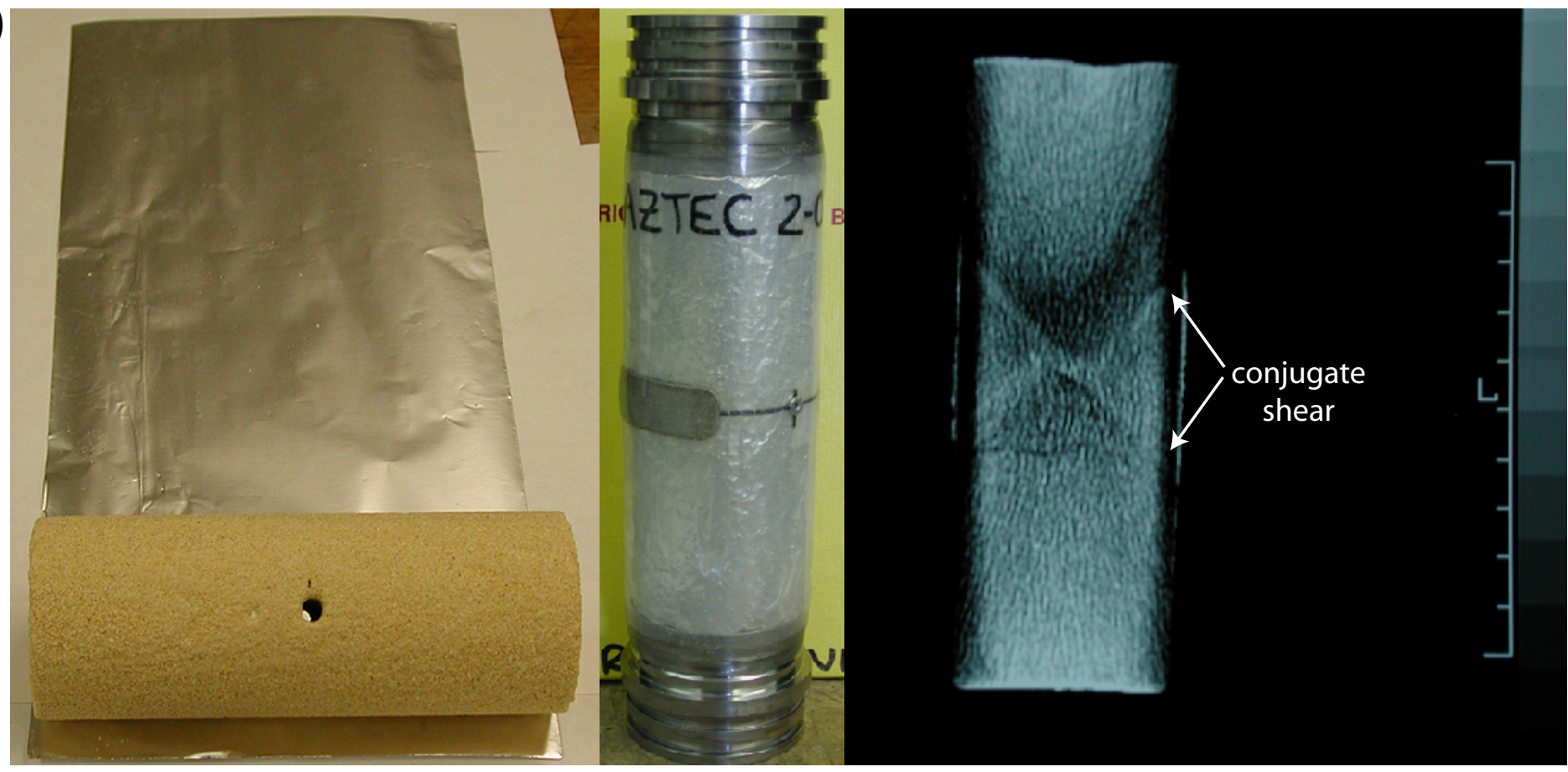

(c)

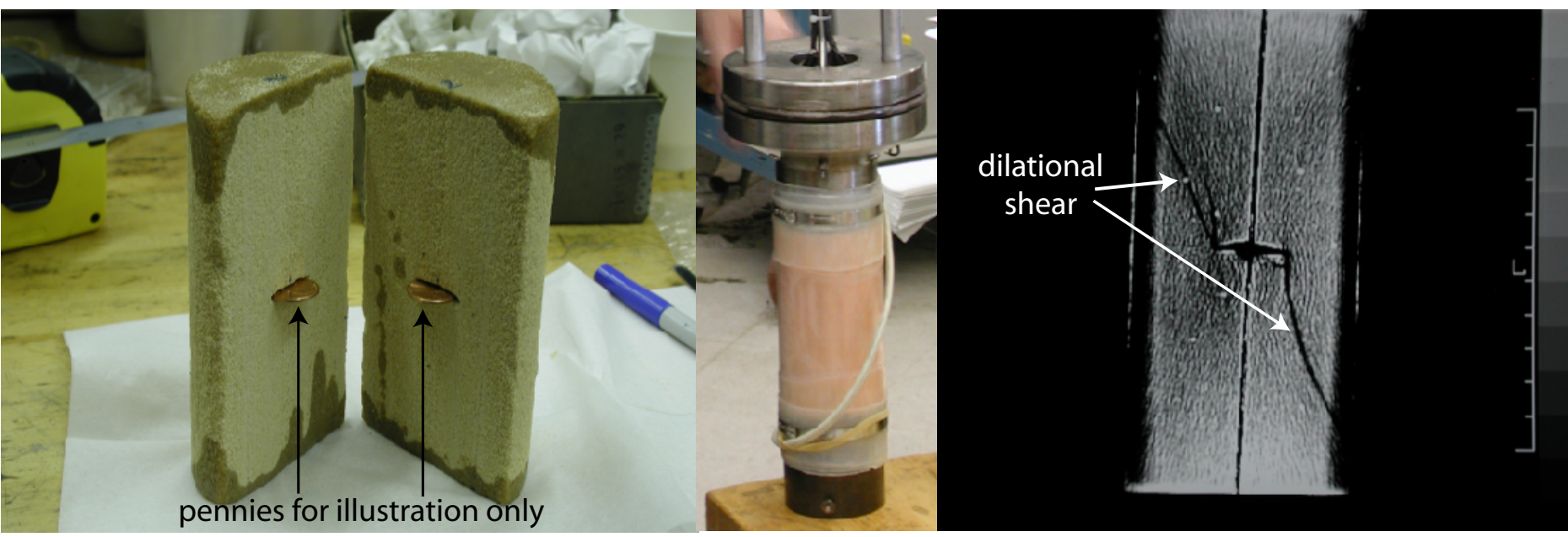

Figure 15. Experimental attempts at anticrack 'proof-of-concept' testing based on the introduction of stressconcentrating initial flaws. (a) At the University of Wisconsin, a 5"x5"x7" block of Aztec was slotted at opposite ends and loaded in true triaxial compression to $60 \mathrm{MPa}$. Subsequent CT scanning revealed that significant anticrack deformation had not localized ahead of the slots. (b) At Sandia National Lab, several 2" diameter specimens of Aztec cored parallel to bedding and drilled through the middle with $5 \mathrm{~mm}$-diameter holes were loaded in standard triaxial compression at confining pressures up to $110 \mathrm{MPa}$. Compactive failure did localize around the flaws at differential stresses in excess of $100 \mathrm{MPa}$, but CT scans revealed it to have generally occurred by conjugate shearing. (c) At U.S.G.S. Menlo Park, a 3"-diameter specimen of Aztec cored parallel to bedding was split in two, seeded with a penny-shaped flaw, reassembled and loaded in standard triaxial compression at $10 \mathrm{MPa}$ confining pressure. Failure did localize around the flaw at about $40 \mathrm{MPa}$ differential stress, but occurred as dilational shearing. 
Flodin, E. A., Durlofsky, L. J. and Aydin, A., 2004, Upscaled models of flow and transport in faulted sandstone: boundary condition effects and explicit fracture modeling. Petroleum Geosciences, v. 10, p. 173-181.

Flodin, E. A., Gerdes, M., Aydin, A., and Wiggins, W. D., 2005, Petrophysical properties of cataclastic fault rock in sandstone. In: Fault Seals and Petroleum Traps, AAPG Memoir. (in press).

Eichhubl, P., Taylor, W. L., Pollard, D. D., and Aydin, A., 2004, Paleo-fluid flow and deformation in the Aztec Sandstone at the Valley of Fire Nevada-Evidence for the coupling of hydrogeological, diagenetic, and tectonic processes. Geological Society of America Bulletin, v. 116, p. 1120-1136.

Aydin, A., Borja, R. I., and Eichhubl, P., 2004, Geological and Mathematical framework for failure modes in granular rock. Journal of Structural Geology (accepted).

Borja, R. I., and Aydin, A., 2004, Computational modeling of deformation bands in granular media, I: Geological and mathematical framework. J. Computational Mechanics, Special Issue, v. 193, p. 2667-2698.

Myers, R; Aydin, A., 2004; The evolution of faults formed by shearing across joint zones in sandstone. Journal of Structural Geology, v. 26, no.5, p.947-966.

Sternlof, K.R., Chapin, J.R., Pollard, D.D., and Durlofsky, L.J., 2004, Permeability Effects of Systematic Deformation Band Arrays in Sandstone: American Association of Petroleum Geologists Bulletin, v. 88, p. 1,315-1,329.

\section{Rock Fracture Project Reports and Dissemination of Results to Industry:}

Eichhubl, P., 2001, Paleo-fluid flow indicators: Stanford Rock Fracture Project, Stanford University, vol. 12, p. C1-C10.

Flodin, E.A., and Durlofsky, L.J., 2001, Representation of fault zone permeability in reservoir flow models: Stanford Rock Fracture Project, Stanford University, vol. 12, p. D1-D10.

Sternlof, K., 2001, Do deformation bands make sense in an idealized linear-elastic world? Stanford Rock Fracture Project, Stanford University, vol. 12, p. P-K1 to P-K9.

Eichhubl, P. and Du Bernard, X., 2002, Fluid flow properties of deformation band faults: Effects of loading conditions, sandstone composition, and burial diagenesis. Stanford Rock Fracture Project, Stanford University, vol. 13, p. P-D1 to P-D5.

Eichhubl, P., and Davatzes, N., 2002, Structural Control of Fluid Flow and Cementation along the Moab Fault, Utah. Stanford Rock Fracture Project, Stanford University, vol. 13, p. C1C15.

Flodin, E. A., 2002, Evolution of a strike-slip fault network in sandstone. Stanford Rock Fracture Project, Stanford University, vol. 13, p. D1 to D12.

Flodin, E. A., 2002, Petrophysical properties of cataclastic fault rock: preliminary results, Stanford Rock Fracture Project, Stanford University, vol. 13, p. P-F1 to P-F8.

Sternlof, K.R., 2002, Compactive deformation bands in sandstone: theoretical concepts, experimental results and field constraints: Stanford Rock Fracture Project, Stanford University, vol. 13, p. PK1-PK10.

Sternlof, K.R., 2003, Modeling compaction localization in sandstone: A new field-based experimental approach. Stanford Rock Fracture Project, Stanford University, vol. 14, p. A1A10. 
Eichhubl, P., and Taylor, W. L., 2003, Valley of Fire, Nevada: An exhumed paleo-fluid migration pathway in a faulted sandstone reservoir. New data and interpretation. Stanford Rock Fracture Project, Stanford University, vol. 14, p. B1-B14.

Davatzes, N., and Aydin, A., 2004, Fault linkage and evolution of the fault core in sandstone, Valley of Fire Nevada: A preliminary report. Rock Fracture Project Workshop, v. 15, E-1 to E-9.

Sternlof, K.R., 2004, Cretaceous-Tertiary reservoir potential of the Aztec Sandstone: a paleo production assessment. Stanford Rock Fracture Project, Stanford University, vol. 15, p. H1H12.

Chopra, G., and Sternlof, K.R., 2004, Elastic boundary element modeling of compaction band propagation and interaction. Stanford Rock Fracture Project, Stanford University, vol. 15, p. P-B1-P-B8.

\section{Abstracts and Papers Presented at National and International Meetings}

Du Bernard, X., Eichhubl, P., and Aydin, A., 2001, Strain localization in sandstone: Eos Trans., American Geophysical Union, vol. 82, no. 47, p. F1188.

Sternlof, K., and Pollard, D.D., 2001, Deformation bands as linear elastic fractures: Progress in theory and observation: Eos Trans., American Geophysical Union, v. 82, no. 47, p. F1222.

Flodin, E.A., Aydin, A., and Durlofsky, L.J., 2001, Representation of fault zone permeability in reservoir flow models: SPE Annual Meeting, New Orleans, September 2001, paper \#71617, 10p.

Du Bernard, X., Eichhubl, P., and Aydin, A., 2002, Deformation bands in sandstones: fluid pathways or barriers: AAPG Annual Convention Official Program, vol. 11, p. A45.

Aydin, A., 2002, Volume change during rock/unconsolidated sediment failure and its role in determining the failure mode, Gordon Research Conference, Rock Deformation, Il Ciocco, Italy May 19-25.

Eichhubl, P., Davatzes, N. C., and Aydin, A., 2002, Structurally controlled fluid flow and diagenesis along the Moab fault, SE Utah: Organic-inorganic interactions and their effects on fault cementation: supplement to EOS, vol. 83, no. 47, abstract T12G-03.

Eichhubl, P., Davatzes, N. C., and Aydin, A., 2002, Diagenetic sealing of fault-controlled hydrocarbon migration pathways: The Moab fault, SE Utah, USA. $18^{\text {th }}$ General Meeting of the International Mineralogical Association Edinburgh, Scotland, Programme with Abstracts, p. 301.

Sternlof, K., and Pollard, D.D., 2002, Numerical modeling of compactive deformation bands as granular anticracks: Eos Trans., American Geophysical Union, v. 83, no. 47, p. F1347.

Aydin, A., and Borja, R. I., 2002, Geological and mathematical framework for failure modes in granular rocks. EOS Trans., v. 83(47), p. F1345.

Aydin, A., Davatzes, N., and Flodin, E., 2003, Conjugate faults in the brittle realm: Old and new perspectives, GSA Annual Meeting, Seattle, WA.

Sternlof, K., Pollard, D.D., and Chopra, G., 2003, Compaction bands as anticracks in sandstone: Taming complexity through integrated observation, experimentation and process-based simulation, GSA Annual Meeting, (15-3), Seattle, WA. 
Eichhubl, P., Taylor, W. L., Pollard, D. D. and Aydin, A., 2003, Effects of structural and depositional heterogeneities on fluid flow in an exhumed sandstone aquifer: The Aztec sandstone at the Valley of Fire, Nevada, GSA Annual Meeting, (20-13), Seattle, WA.

Aydin, A., Analysis of faults on the surface of Jupiter's moon Europa based on failure modes. EOS Trans., v. 85, AGU Fall Meeting, San Francisco, CA.

Davatzes, N. C., Eichhubl, P., and Aydin, A., 2003, Fault Seal and Conduit Dichotomy: Impact of Deformation Mechanism and Fault Geometry: AAPG Annual Convention Official Program, vol. 12, p. A36.

Sternlof, K., Flodin, E., Eichhubl, P., Aydin, A., and Pollard, D., 2003, Structural Heterogeneities and Paleo-Fluid Flow in an Analog Sandstone Reservoir: AAPG Annual Convention Official Program, vol. 12, p. A163.

Du Bernard, X., Eichhubl, P., and Aydin, A., 2003, Three types of deformation bands and their micromechanics in sandstone. Geophysical Research Abstracts, vol. 5, 08276.

\section{Invited Lectures}

Sternlof, K., and Pollard, D.D., 2002, Compactive Deformation Bands in Sandstone: Field Insights into the Mechanics of Compressive Failure in Granular, Porous Materials. Sandia National Laboratory, Albuquerque, New Mexico, February 21.

Aydin, A., 2002, Volume change during rock/unconsolidated sediment failure and its role in determining the failure mode, Gordon Research Conference on Rock Deformation, Il Ciocco, Italy May 19-25.

Eichhubl, P., and Davatzes, N. C., 2002, Coseismic and postseismic fluid flow and mineralization: field-based observations. Hubbert Quorum, USGS Menlo Park, CA December 5.

Eichhubl, P., Davatzes, N. C., and Aydin, A., 2002, Diagenetic sealing of fault-controlled hydrocarbon migration pathways: The Moab fault, SE Utah, USA. 18th General Meeting of the International Mineralogical Association, Edinburgh, UK, September 4.

Eichhubl, P., 2002, Fault-controlled fluid flow in fractured Monterey Formation of the Santa Barbara Basin, California. Petroleum Technology Transfer Council, Ventura, California, July 17.

Eichhubl, P., 2002, Faults and the flow of fluids in the Earth's crust. International University Bremen, Bremen, Germany, June 30

Pollard, D.D., 2003, Propagation of compaction bands - field observations, lab experiments, and numerical models of anticracks. Department of Geosciences, Univ. of Massachusetts, Amherst, MA, March 28.

Pollard, D.D. and Sternlof, K., 2004, Effective permeability of sandstone containing deformation band arrays at the outcrop and reservoir scales. Flow and Transport: Characterization and Modeling from Pore to Reservoir Scales. DOE-BES Workshop, Gaithersburg, MD.

Aydin, A., 2004, Characterization of paleo fluid flow through faults and fractures. Flow and Transport: Characterization and Modeling from Pore to Reservoir Scales. DOE-BES Workshop, Gaithersburg, MD.

Aydin, A., 2004, Framework for volumetric deformation bands in geological and engineering materials: kinematics, geometry, scale, and processes. DOE-BES Compaction Workshop, Warrenton, VA. 
Sternlof, K., and Pollard, D.D., 2004, Compaction band occurrence in the Aztec sandstone: field constraints on experimentation and theory. DOE-BES Compaction Workshop, Warrenton, VA.

\section{Ph. D. theses}

Flodin, E. A., 2003, Structure, petrophysics and permeability of faults in sandstone, Valley of Fire, Nevada. Stanford University, $180 \mathrm{pp}$.

Sternlof, K., (in prep., 2005), Compaction bands in the Aztec sandstone, Valley of Fire, Nevada. Stanford University, _ pp. 